Florida International University

FIU Digital Commons

FIU Electronic Theses and Dissertations

University Graduate School

3-29-2013

\title{
The Relationship between Faculty Perceptions and Implementation of Elements of Transactional Distance Theory and Online Web-Based Course Completion Rates
}

Victor Nwankwo

Florida International University, vnwan001@fiu.edu

DOI: $10.25148 /$ etd.FI13042504

Follow this and additional works at: https://digitalcommons.fiu.edu/etd

Part of the Curriculum and Instruction Commons

\section{Recommended Citation}

Nwankwo, Victor, "The Relationship between Faculty Perceptions and Implementation of Elements of Transactional Distance Theory and Online Web-Based Course Completion Rates" (2013). FIU Electronic Theses and Dissertations. 875.

https://digitalcommons.fiu.edu/etd/875 


\section{FLORIDA INTERNATIONAL UNIVERSITY}

Miami, Florida

THE RELATIONSHIP BETWEEN FACULTY PERCEPTIONS AND

\section{IMPLEMENTATION OF ELEMENTS OF TRANSACTIONAL DISTANCE THEORY}

AND ONLINE WEB-BASED COURSE COMPLETION RATES

A dissertation submitted in partial fulfillment of the

requirements for the degree of

DOCTOR OF EDUCATION

in

CURRICULUM AND INSTRUCTION

by

Victor Ikechukwu Nwankwo

2013 
To: Dean Delia C. Garcia

College of Education

This dissertation, written by Victor Ikechukwu Nwankwo, and entitled The Relationship between Faculty Perceptions and Implementation of Elements of Transactional Distance Theory and Online Web-Based Course Completion Rates, having been approved in respect to style and intellectual content, is referred to you for judgment. We have read this dissertation and recommend that it be approved.

Janice Sandiford

$\begin{array}{r}\hline \text { Aixa Perez-Prado } \\ \hline \text { Suman Kakar }\end{array}$

M. O. Thirunarayanan, Co-Major Professor

Leonard B. Bliss, Co-Major Professor

Date of Defense: March 29, 2013

The dissertation of Victor Ikechukwu Nwankwo is approved.

$\begin{array}{r}\hline \begin{array}{r}\text { Dean Delia C. Garcia } \\ \text { College of Education }\end{array} \\ \hline \begin{array}{r}\text { Dean Lakshmi N. Reddi } \\ \text { University Graduate School }\end{array}\end{array}$

Florida International University, 2013 


\section{DEDICATION}

I dedicate this dissertation to my mother Bernice Nwankwo, to my wife Ebele Nwankwo, and to my children Tobechukwu and Ogechi Nwankwo. Their unconditional love and support helped me bring this dissertation to completion. Again, I immensely thank them for all their sacrifices and for providing the exceptional support that this project required. 


\section{ACKNOWLEDGMENTS}

I would like to extend my deepest appreciation and gratitude to the members of my committee for their exceptional expertise and guidance in assisting me throughout the process of completing this dissertation: Dr. Mandayam Thirunarayanan, Co-Chairperson; Dr. Leonard Bliss, Co-Chairperson; Dr. Janice Sandiford; Dr. Aixa Perez-Prado; and Dr. Suman Kakar. I believe that their constructive feedbacks and assistance greatly improved this dissertation. I also want to thank Dr. Linda Bliss for her exceptional attention to details and for helping me complete this process. I personally take full responsibility for any errors, typos, etc. that may still exist in this document.

Of course, I would remiss if I failed to specially thank my brothers and sisters who provided me with encouragement and an unwavering support for the extra mile needed to complete this challenging task. 


\author{
ABSTRACT OF THE DISSERTATION \\ THE RELATIONSHIP BETWEEN FACULTY PERCEPTIONS AND \\ IMPLEMENTATION OF ELEMENTS OF TRANSACTIONAL DISTANCE THEORY \\ AND ONLINE WEB-BASED COURSE COMPLETION RATES \\ by
}

Victor Ikechukwu Nwankwo

Florida International University, 2013

Miami Florida

Professor M. O. Thirunarayanan, Co-Major Professor

Professor Leonard B. Bliss, Co-Major Professor

The purpose of this study was to explore the relationship between faculty perceptions, selected demographics, implementation of elements of transactional distance theory and online web-based course completion rates. This theory posits that the high transactional distance of online courses makes it difficult for students to complete these courses successfully; too often this is associated with low completion rates. Faculty members play an indispensable role in course design, whether online or face-to-face. They also influence course delivery format from design through implementation and ultimately to how students will experience the course.

This study used transactional distance theory as the conceptual framework to examine the relationship between teaching and learning strategies used by faculty members to help students complete online courses. Faculty members' sex, number of years teaching online at the college, and their online course completion rates were considered. A researcher-developed survey was used to collect data from 348 faculty 
members who teach online at two prominent colleges in the southeastern part of United States.

An exploratory factor analysis resulted in six factors related to transactional distance theory. The factors accounted for slightly over $65 \%$ of the variance of transactional distance scores as measured by the survey instrument. Results provided support for Moore's (1993) theory of transactional distance. Female faculty members scored higher in all the factors of transactional distance theory when compared to men. Faculty number of years teaching online at the college level correlated significantly with all the elements of transactional distance theory. Regression analysis was used to determine that two of the factors, instructor interface and instructor-learner interaction, accounted for $12 \%$ of the variance in student online course completion rates.

In conclusion, of the six factors found, the two with the highest percentage scores were instructor interface and instructor-learner interaction. This finding, while in alignment with the literature concerning the dialogue element of transactional distance theory, brings a special interest to the importance of instructor interface as a factor. Surprisingly, based on the reviewed literature on transactional distance theory, faculty perceptions concerning learner-learner interaction was not an important factor and there was no learner-content interaction factor. 


\section{TABLE OF CONTENTS}

CHAPTER

PAGE

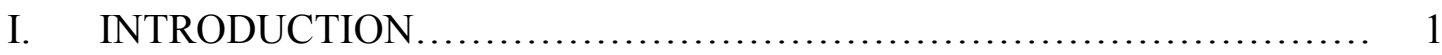

Theoretical Framework............................................. 2

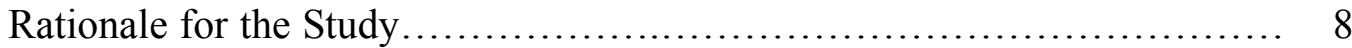

Research Questions................................................ 9

Population for the Study ............................................. 9

Significance of the Study .............................................. 9

Delimitations of the Study .......................................... 10

Operational Definition Terms......................................... 10

Organization of the Study ............................................. 12

II. LITERATURE REVIEW............................................ 14

Why Students Drop out of Distance Education.......................... 14

Review of Literature Related to Transactional Distance Theory............. 17

Empirical Studies Related to Transactional Distance Theory (TDT)......... 21

Interaction Affecting Transactional Distance ............................ 25

Learner-Instructor Interaction..................................... 28

Learner-Learner Interaction......................................... 29

Learner-Content Interaction....................................... 31

Experience and Sex of Faculty Member............................. 31

Summary of Literature Review...................................... 33

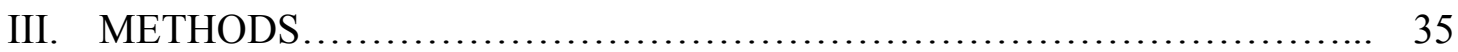

Participants and Sampling............................................. 37

The Data Collecting Instrument..................................... 37

Instrument Validation............................................ 38

Instrument Description............................................ 38

Data Collection Procedures............................................ 39

Research Design................................................... 40

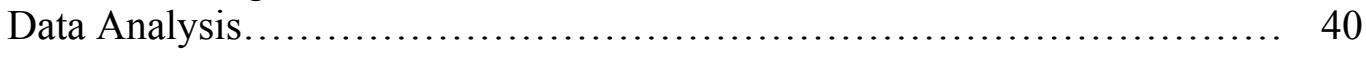

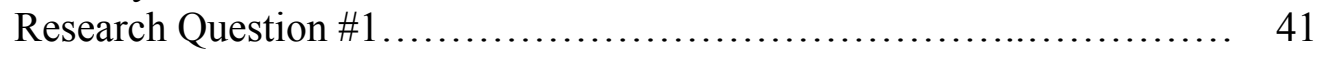

Research Question \#2 ........................................... 41

Research Question \#3............................................ 42

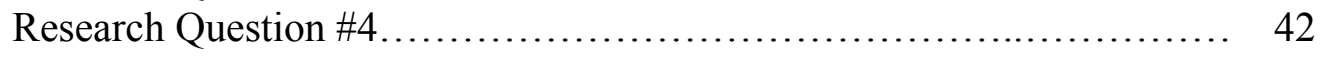

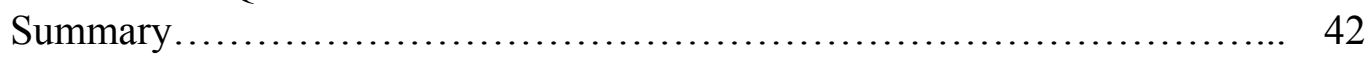


IV. DATA ANALYSIS AND FINDINGS ............................. 44

Summary of Survey Response Rate.................................. 44

Survey Response Rate.......................................... 45

Descriptive Analysis.............................................. 46

Data Gathering Instrument....................................... 48

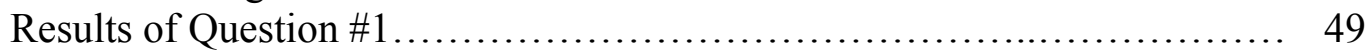

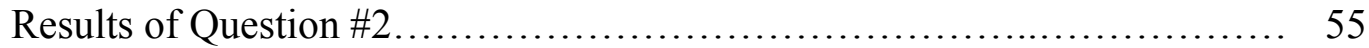

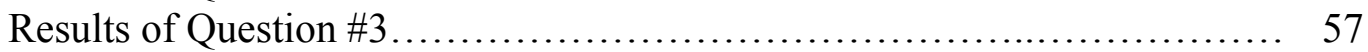

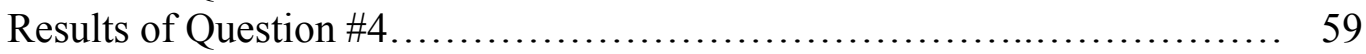

V. DISCUSSION, CONCLUSIONS, AND RECOMMENDATIONS.......... 61

Restatement of the Problem............................................. 61

Review of the Methods Used...................................... 62

Summary of the Results............................................ 63

Discussions of Findings......................................... 66

Transactional Distance Factors Based on Research Instrument............ 66

Limitations of the Study........................................... 68

Implications for Research ..................................... 69

Recommendations for Further Research............................ 71

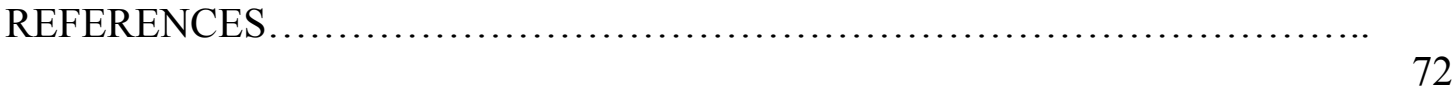

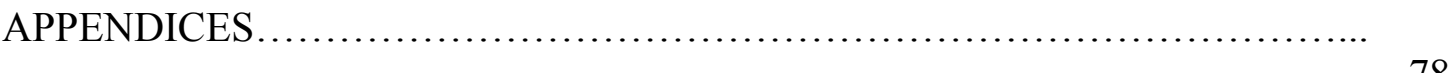

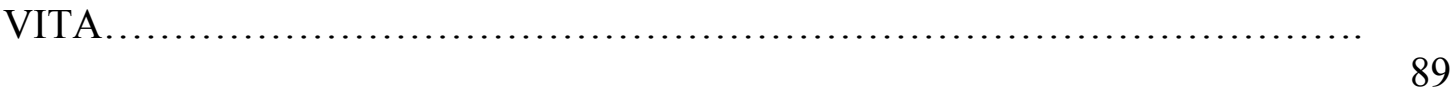




\section{LIST OF TABLES}

TABLE

PAGE

1. Sex Distribution of Survey Participants for Both Institutions............ 47

2. Faculty Course Design and Development........................... 48

3. Top Three Loading of Items in Each of the Six Factors of the

Transactional Distance Attitude Survey.......................... 50

4. Factor Percentage Scores....................................... 52

5. Results of Planned Comparisons between Mean Percent Scores of the

Six Factors................................................... 53

6. Men and Women Descriptive Scores on Elements of Transactional

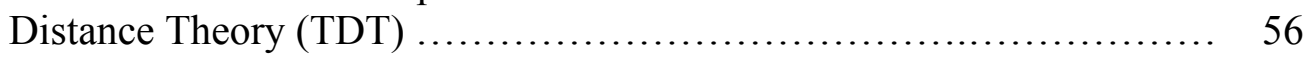

7. Analysis of Variance for Differences in Mean Scores by Sex.............................................................. 58

8. Regression Transactional Distance Theory (TDT) and Completion

Rate....................................................... 60 


\section{CHAPTER I}

\section{INTRODUCTION}

The need for online and web-based education continues to grow as more colleges and universities find creative ways of reaching beyond their traditional brick and mortar boundaries (Braun, 2008) to reach all students. Because of the popularity of web-based courses, most colleges and universities currently are offering online courses and some even offer complete online degree programs (Wilkes, Simon, \& Brooks, 2006). Given these demands and current trends, many of these colleges "are actively engaged in the development of online courses and bringing their on-campus courses to the online environment" (Steinman, 2007, p. 50). However, faculty perceptions and pedagogical prerogatives often are neglected in the design, development, and implementations of these online courses as much effort and concentration are focused on perceived learner outcomes and learner satisfaction with the course.

The concept of physical separation of instructors and students is not new in education. According to Rumble (2001), the history of distance education dates back to at least 1840 in England, when Sir Isaac Pitman took advantage of cheap penny postal deal and started teaching shorthand using correspondence teaching techniques. Schlosser and Anderson (1994) stated that "the roots of distance education are at least 150 years old" (p. 2). Moore and Kearsley (2005) also observed that one of the principal motives for the early correspondence education was the vision of using technology to reach out to those who otherwise were constrained in both time and location. Schlosser and Anderson (1994) observed that the original objective groups for distance education effort were mostly adults with work-related, societal, and personal obligations. Although this remains 
the primary target group for distance education, there has been a greater effort in recent years to provide it to all students including high school, middle school, and elementary school students.

From the original correspondence course where materials were mailed to students, to radio and television, and ultimately to computers and digital media where various combinations of text, audio, video, animation, graphics, and virtual reality can be used to create new forms of interactions, it is clear that these technologies are blurring the line between face-to-face and online-based distance education courses. The rapid growth and availability of these new technologies in education have ushered in "applications that are changing the pedagogic assumptions upon which distance education is founded" (Rumble, 2001 p. 31). Despite these potentials, little attempt has been made to develop an empirical understanding of these pedagogical changes and their impact, especially on those instructors who are expected to use them to deliver their online courses to students. Schlosser and Anderson (1994) noted that "there was steady expansion of distance education, without radical changes in structure, but with gradually more sophisticated methods of and media employed" (p. 4). It is clear that as these new forms of technologies are made available, teachers most often are required to devise effective means of adopting, adapting, and integrating these technologies into their respective courses to transform their teaching and learning in both face-to-face and online teaching and learning environments.

\section{Theoretical Framework}

Theoretical frameworks for distance education have continued to evolve, progressing from organizational and structural issues to transactional issues and 
assumptions (Garrison, 2000). Charles Wedemeyer has been credited with transitioning distance education from correspondence course to independent study shifting focus to the learner (Garrison, 2000; Keegan, 1986; Schlosser \& Anderson 1994). According to Garrison (2002), this focus on the learner signaled a shift to pedagogical assumptions of the independent learner: greater learner autonomy, more self-directed learning, placing greater responsibility for learning on the learner, providing greater opportunities for learners to take more control of their learning, and freeing educators from organizational and administrative issues to where they can provide help more readily to the learner (Schlosser \& Anderson 1994).

Garrison (2000) described Otto Peter's industrial model theory of distance education as "the most coherent rigorous and pervasive example of distance education theory" but argues that it "was not a theory of teaching or of learning, but rather a contribution to clear thinking about organization of distance learning" (Garrison, p. 5). Garrison goes on to state that "the dominance of structural and organizational concerns of the industrial model, over teaching and learning issues, is central to understanding theoretical developments and challenges we face in developing distance education theory in this century" (p. 6).

Following Peter's industrial model theory of distance education was “Borje Holmberg's guided didactic conversation which refers to both real and simulated conversations" (Garrison, 2000, p. 4). The concept of guided didactic conversation places upon distance education course designers the responsibility of being able to create simulated conversation through the use of well-prepared course materials. Garrison (2000) argues that despite Holmberg's great effort to make teaching the central core of 
his theory, some of Holmberg's structural assumptions about self-study learning packages limit teaching to one-way communication only.

In articulating his transactional distance theory, Michael Moore seemed to have addressed the structural limitations found in Holmberg's theory of distance education by adding dialogue (Garrison, 2000; Moore, 1990; Moore \& Kearsley, 1996). Moore's (1993) first articulation of transactional distance theory appeared in 1972, derived from Dewey's concept of education as a transaction. Expanding on this concept of transaction, Moore (1993) stated "that distance education is not simply a geographic separation of learners and teachers, but, more importantly, that distance education is a pedagogical concept" (p. 22). Moore contended that with the separation of learner and teacher, "there is a psychological and communication space to be crossed, a space of potential misunderstanding between the inputs of an instructor and those of a learner" ( $p$. 23). It is this psychological and communication space that becomes the transactional distance.

Rumble (1986) observed that transactional distance exists in all educational settings including face-to-face. Moore (1993) posited that as a psychological phenomenon transactional distance is a continuous variable that is different and varies for each learner and teacher. The greater the transactional distance the more difficult it will be for the student to understand course content and perform well in the course, and the more difficult it might be for the teacher to interact with students and assist students in understanding what is being taught. Moore (1993) theorized that:

The extent of transactional distance in an educational programme is a function of these three sets of variables. These are not technological or 
communications variables but variables in teaching and in learning and in the interaction of teaching and learning. These clusters of variables are named Dialogue, Structure, and Learner Autonomy. (p. 23)

Moore defined the dialogue variable as a positive interaction that is purposeful and constructive and valued by both teacher and learner. For educational goals and purposes, more dialogue with the teacher and other students will lead to improvements in student understanding of the subject matter under study. He stated, "whether dialogue occurs, its extent and nature is determined by the educational philosophy of the individual or group responsible for the design of the course, by the personalities of teacher and learner, by the subject-matter of the course, and by environmental factors" (Moore, 2001, p. 24). The instructor plays an indispensable role in how the elements of transactional distance are structured in a course to make it conducive for the learners to maximize their learning potential. A teacher can influence how much interaction is incorporated into course design, including how much and how often feedback is provided as well as the level of control provided to the learner.

According to Basow (1995), in her 4-year period of analysis of effects of teacher sex and student sex and divisional affiliation in a private liberal college, "female professors tended to receive their highest ratings from female students and their lowest rating from male students" (p. 656), while rating for male professors were unaffected by student sex. However, in a more recent study of student evaluation of quality of instruction, $\mathrm{Ou}$ (2011) found "that in a distance education setting, gender and class size are no longer significant predictors of quality of instruction" (p. 471). In their study of online teaching efficacy of nurse faculty, Robina and Anderson (2010) found that 
"primarily the highest levels of online teaching efficacy resulted after teaching at least three online courses" (p. 168).

Some of the required responsibilities of a teacher in any course design must include how to organize various elements of the course and take into account how materials are arranged and presented to the student. How rigid or flexible a course structure is can affect learners if they are allowed to determine the course content, order of presentation, what to learn, when to learn, and how to learn. According to Moore (1993), such qualitative characteristics of a course as structure and dialogue can both be can be affected by the degree of the technological media being used, by "philosophical and emotional characteristics of teachers, by the personalities and other characteristics of learners, and by the environment provided by the educational institution where the course is being offered" ( p. 23).

An increase in transactional distance means that the learner must work harder in order to overcome or reduce the amount of transactional distance to an acceptable level in order to complete the course successfully. Thus, teachers and other instructional designers can and do play an essential role in determining how flexible and how rigid an online course structure will be for learners. The extent of dialogue and flexibility of structure either increases or decreases transactional distance for students. "There appears to be a relationship between dialogue, structure and learner autonomy, for the greater the structure and lower dialogue in a programme the more the autonomy the learner will exercise" (Moore, 1993, p. 27). Thus, successful teaching in online distance education depends on the specific instructor creating the suitable chances for discourse between teacher and student as well as on the instructor configuring learning materials properly in 
order to meet the learning requirements of the student and eventually providing an atmosphere that will be conducive for students to take more charge for their own learning.

Beaudoin (1990) observed this evolving transformational role of the instructor and stated that in order for students to become more successful in learning, the instructor must transcend the current role to one that will recognize how technological innovations can generate greater access to education by overcoming time and distance difficulties, and how technology can deliver diverse learning needs because of its propensity to convey material in many different instructional modes. Ideally, digital technologies can be used by instructors to create learning environments that can stimulate learners to become more active and more independent in self-selecting those methods that are more effective and efficient in meeting their learning needs and demands. According to Moore (1993), learner autonomy also is an important factor that might affect the extent of transactional distance for learners in any particular course. He describes learner autonomy as "the extent to which in the teaching and learning relationship it is the learner rather than the teacher who determines the goals, the learning experiences and the evaluation decisions of the learning program" (p. 31). Technology empowers students to take more control of their learning needs. Proper technology integration also helps teachers to transition into facilitators providing help and tailoring guidance where appropriate for each individual student, and scaffolding where appropriate. These fluid changes within the new teaching and learning environment means that for teachers to be effective, they also must be engaged and conversant with emerging technologies that enhance teaching and learning. 
Therefore, there is a need to establish an understanding of the kinds of activities online teachers should be employing in their teaching and learning in order to have an effective and successful online course for their students. During course design, all things being equal, most instructors engage in a personal goal of creating the best learning platform and learning experience for their students. Regardless of each teacher's personal goals for a course, there are certain basic principles that must be established and core values that must be woven into a course as it is being designed. A good understanding of faculty implementation of elements of transactional distance as has been articulated in Moor's theory (1993) can lead to establishing the kinds of pedagogical strategies that will enhance learning outcomes for distance education students. In addition to the elements of transactional distance theory, there are certain institutional provisions that may influence how faculty members structure online courses. Oftentimes, this might include providing a learning management system, providing a master course with selected objectives that must be covered in that particular course, setting a time limit for an online course, and providing rules that govern course creation and delivery methods and options. How technology is integrated and used and invariably how it affects transactional distance for both teachers and students should be of great interest to those involved in providing instructional support to instructors and learners.

\section{Rationale for the Study}

Most studies in distance education, especially those that relate to transactional distance theory, have focused mainly on student perception, success rates, attrition, and motivation (Chen, 2001; Chen \& Willits, 1999; Saba \& Shearer, 1994; Urtel, 2008). 
However, little has been done empirically to understand how perceptions of faculty relate to the elements of transactional distance theory.

The purpose of this study is to answer the following research questions:

\section{Research Questions}

1. What are online instructors' perceptions of elements of transactional distance theory?

2. Is there a relationship between faculty self-reported implementation of elements of transactional distance theory in their online courses with regard to faculty sex?

3. Is there a relationship between faculty self-reported implementation of elements of transactional distance theory in their online courses and their number of years teaching online?

4. Is there a relationship between faculty self-reported perceptions, implementations of elements of transactional distance theory, and student online course completion rates?

\section{Population for the Study}

The target population for this study was faculty who teach online web-based distance learning courses in colleges in Florida, the southeastern part of the United States. Data were collected from two large colleges with diverse populations of both faculty and students.

\section{Significance of the Study}

Increased understanding of how faculty perceive and implement factors of transactional distance will assist administrators and those associated with developing and 
delivering online courses to better provide instructors with the necessary tools they need to structure online courses effectively in order to reduce transactional distance for most students and ultimately to increase online course completion rates for students. For example, if instructors who use a particular set of tools perceive that these tools are effective in reducing transactional distance, then institutions can work on helping faculty incorporate those tools into their online web-based courses through training and provision of the tools.

The findings of this study have the potential to help faculty trainers to more effectively structure training programs for online instructors and other professionals involved in online course delivery to directly address and reduce those factors that might adversely affect transactional distance for students.

\section{Delimitations and the Scope of the Study}

While the problem that was investigated is of concern to all distance education programs, especially those that use web-based technologies, this study was limited to colleges. Colleges tend to offer more distance education courses than most universities. Two large urban colleges with high proportions of minority and underprepared students in the southeastern part of the United States were used for this study.

\section{Operational Definition of Terms}

Face-to-face course (F-2-F): an instructor led course that might include minimal use of technology; instructor and the student usually are not separated in time and/or distance as in distance education. 
Online web-based course (online course): a course in which the majority of course activities are completed online, where there may be a separation of the learners and/or teachers.

Transactional distance: the psychological distance of misunderstandings and perceptions that may lead to a communication gap between the learner and the instructor of a course. It can be described as a "psychological space of potential misunderstandings" (Moore, 1993, p. 23) between teachers and students and among students engaged in educational transaction. In this study, transactional distance was examined within the context of a web-based learning environment. Given the role teachers play in determining the extent and the amount of transactional distance available during course design and delivery, an attempt was made to determine how instructors perceive this transactional distance within their web-based distance education courses.

Dialogue: two-way communication between student and teacher and among students. It may take various forms including synchronous and asynchronous messages using several electronic means such as e-mail or chat, audiovisual elements, facsimile, instant messaging, or any form of communication that is used to enhance teaching and learning for the students. In this study, instructors were requested to rate their frequency of using various means of communications between themselves and their students.

Structure: the common elements of course design that influence the amount of flexibility and rigidity that students are allowed in the course. For instance, in a webbased course, structure might provide various means of delivering assignments, when and if there is a fixed date for turning assignments, various collaborative work among students, team assignments and how they are structured, attendance, choice or lack of it 
in completing assignments, what is graded and what is optional for students, methods of presentations, demonstrations, and forms of discussion allowed and encouraged both among students and with the instructor.

Learner autonomy: the extent to which the students perceive their responsibility for influencing their own learning. This includes their perception of independence and interdependence for their learning with and without other students and the instructor. How do teachers perceive a student's ability to learn independently or to work collaboratively with other students in completing assignments? For this study, instructors were required to rate how they perceived their students with regard to the rate of independence and interdependence in their web-based course.

Learner interface: the use of various technologies for delivering course content to students. In most cases, instructor interface also might affect course structure based on use of learning management systems. Course learning management system might influence what is provided for students in terms of communication tools, methods, and the extent of the use of various means of interactive communications.

\section{Organization of the Study}

The first chapter provided a brief description of the study, the statement of the problem, theoretical framework, significance of the study, purpose, research questions, operational definition of terms, and organization of the study. Chapter 2 includes a review of literature related to transactional distance theory and its practical application as it relates to student participation and satisfaction in online web-based courses. Chapter 3 provides a description of research design with data collection and rationale for research methods used in data analysis. Chapter 4 addressed findings and data collection analysis. 
Chapter 5 includes discussions, implications, and the interpretation of collected data, with conclusions regarding transactional distance and how it relates to online course completion rates. There also are recommendations for future research. 


\section{CHAPTER II}

\section{REVIEW OF THE LITERATURE}

This chapter includes a review of research literature pertinent to how the use of technology and digital media are transforming teaching and learning at a distance where instructor and students may be separated in time and/or place. One of the consequences of such separation appears to be the larger number of students who drop out of distance education courses and programs. This chapter begins with a brief review of the literature to understand why larger numbers of students drop out of distance education when compared to face-to-face education, and how instructors' perceptions and implementations of elements of transactional distance theory might relate to online course completion rates.

\section{Why Students Drop Out of Distance Education}

Using an integrative review of research literature regarding student attrition rates especially in distance education courses within the past six years from 2001 to 2006, Angelino, Williams, and Natvig (2007) stated that the issue of higher attrition rate for distance education remains problematic and is about $10-20 \%$ higher than comparable classes taught in a face-to-face environment. In search of higher persistence rates in distance education, Rovai (2003) reviewed two models (Tinto, 1975, 1987, 1993; Bean

and Metzner, 1985) mostly used to address persistence rates in classroom with the intent of deriving a student persistence model that will be more applicable to online learning. Rovai ultimately produced a composite persistence model by combining these two models with special skills and various teaching and learning styles required by online students. He identified five specialized student needs and contends that the degree to 
which they are provided will impact attrition, especially for online students. These student needs are (a) having consistency and clarity of online programs, policies, and practices and procedures; (b) having self-esteem; (c) feeling an identity with the school they do not feel isolated; (d) having social integration that is independent of and interdependent with their social needs concerning their relation to other students, instructors, and other distance education supporting staff; and (e) having support services such as bookstores, library, and tutoring and academic support.

According to Rovai (2003), "good instructional design and pedagogy are the core of high-quality online courses and should be tailored to the medium and to the learning needs and styles of the students" (p. 14). Thus, online instructors and those responsible for the design, implementation, and delivery of online distance education can influence the amount and degree of transactional distance that is associated with a course. Understanding what contributes to successful online course completion and using this information in developing strategic plans for reducing transactional distance can lead to a higher quality online distance education programs for an institution. Rovai concluded that "Most successful retention efforts include program elements that focus on increasing academic integration consisting of active participation and satisfactory experiences where students personally interact with faculty and each other" (p. 14). This supports the notion that active academic integration promotes active student engagement, which should result in reducing transactional distance for students and subsequently increasing course completion rates for online students.

In their research of 147 adult students who either finished or did not finish one of three courses provided between fall 2005 and summer 2007 in a large Midwestern 
university, Park and Choi (2009) used learner variables such as age, sex, and level of education; outside factors such as family and institutional provisions; and internal factors such as contentment and relevance as sub-dimensions of inspiration in an attempt to understand factors affecting adult learners' inclinations to drop out or to persevere in online learning. Park and Choi found "lower dropout rates can be achieved if online program developers or instructors find ways to enhance the relevance of the course" ( $p$. 207) and provide additional support to increase student participation, thus reducing transactional distance for students.

What are some of the pedagogical strategies that can enhance and enrich distance education by lowering transactional distance, and which should encourage students to complete their online based courses? According to Oblender (2002), there is a need to understand what contributes to high rates of dropout that seems to be unique to online distance learning. A good knowledge of what pedagogical strategies are effective in an online environment where technology is being used to replicate face-to-face classroom interactions could contribute to assisting learners to persist and complete their online courses. Issues to consider: What strategies concerning student interactions promote transactional presence and help to scaffold and guide students toward desired instructional goals? What role does faculty perception of the elements of transactional distance play in how faculty structure online activities and select pedagogical strategies including level and amount of control, feedback, student to student communication, communication of course content, and other curricula means and activities to increase student online course completion? 


\section{Review of Literature Related to Transactional Distance Theory}

Based on existing models of distance education, Moore (1993) theorized that as a psychological phenomenon, transactional distance is a continuous variable that is different and varies for each learner and teacher. The greater the transactional distance the more difficult it will be for the student to understand course content and perform well in the course and the more difficult it will be for the teacher to interact and assist students. As noted in Chapter 1, three sets of variables - dialogue, structure, and learner autonomy - determined the extent of transactional distance for students in a course (Moore, 1993). In order to reduce transactional distance for students, especially for online students, great care must be used in orchestrating appropriate levels of dialogue or interaction, in pooling course resources to provide flexible course structure, and in allowing variable learner autonomy to meet individual learning needs of students.

Because faculty members play an indispensable role in how students ultimately experience online courses, Moore (1993) theorized that faculty perceptions, based on personal experiences including their technological background, might influence how they respond to their students' needs, especially for those who might be at a distance. According to Mortera-Gutierrez (2002), despite this important faculty role a number of research studies on distance learning have focused more on the role of distance learners especially on learner perceptions of learning environments (Braun, 2008; Chen, 2001, 2002; Mansour \& Mupinga, 2007) and learner satisfaction with learning strategies (Summers, Waigandt, \& Whittaker, 2005) used in an online class. There has been less emphasis on the role of the instructor especially in instructional design and how this might affect course structure, learner autonomy, and dialogue. This is unfortunate 
because, as Summerset et al. (2005) pointed out, "In distance education, the different instructional design models are influenced by diverse factors (e.g., instructional design components, instructors' strategies, and educational paradigmatic approaches), which determine the amount and quality of instruction and interaction between instructors and their distant learners" (p. 193). In a similar vein, according to Mortera-Gutierrez (2002):

The instructors' paradigmatic approach (e.g., behaviorist, constructivist, or critical theory) affects how interaction and design will impact the degree of transactional distance experienced both students and faculty in an online course. These paradigmatic approaches have major consequences for instructional design and learner outcomes, they serve as conceptual and communication tools for analyzing, designing, creating and evaluating, ranging from broad educational environment to narrow training applications. (p. 193) In support of having a functional definition of interaction, Wagner (1994) stated: Interactions are reciprocal events that require at least two objects and two actions. Interactions occur when these objects and events mutually influence one another. An instructional interaction is an event that takes place between a learner and the learner's environment. Its purpose is to respond to the learner in a way intended to change his or her behavior toward an educational goal. (p. 8)

According to Swan (2004), based on her analysis and review of research literature dealing with relationships between interaction and learning in online environment and given the nature and possibilities existing in configuring course interaction, there is believable evidence to consider that online discussions may be more helpful for 
experimentation; divergent thinking; and examinations of multiple narratives, difficult understanding, and reflection than face-to-face discussions. These methods can add positively to student learning, their increased participation, and their becoming more responsible for their own learning (Jiang \& Ting, 2000; Parker \& Gemino, 2001; Piccano, 2002; Shea et al., 2004), making online learning more attractive even for mainstream students.

The development of the Internet and communication technologies is fostering the creation and proliferation of these powerful emerging interactive media, especially through WorldWideWeb streaming media, audio, video. and mobile learning. These emerging technologies make possible a broader, more powerful development of a repertoire of pedagogical strategies that are helping to transform teaching and learning for distance education especially for those courses that are web-based. These emerging interactive media empower novel types of both teaching and learning experiences; for instance, interpersonal interactions across technologies can lead to the formation of various teaching and learning communities for a class and for new forms of group collaborative projects that were not possible before, thus offering flexible opportunities for reducing transactional distance for students in ways that were not possible in the past and promoting both academic and social integration.

These new and novel media make it possible to change teaching and learning instruction beyond synchronous, teacher classroom controlled and dominated forms of teaching and learning to ultimately empowering students and learners to take more control of their own learning and to contribute in building new forms of interaction to assist in reducing transactional distance. When learners are encouraged to take more 
control of their learning, they also tend to shift from being passive learners to becoming more engaged and being more actively involved in both teaching and learning. As students begin to take more control of their learning, teachers become more of a guide and a facilitator in the teaching and learning environment, thus supporting Moore's (1993) idea of providing "learner autonomy" to students as a way of reducing the degree of transactional distance in a course. According to Moore, "Learner autonomy is the extent to which in the teaching/learning relationship it is the learner rather than the teacher who determines the goals, the learning experiences, and the evaluation decisions of the learning programme" (p. 31). This only can be possible when instructional designers have made adequate accommodations during instructional design to allow such flexibility.

According to (Moore, 1993), distance education can be classified as a transaction and the gap between teacher and student basically is a psychological space that has a potential for misunderstanding. This psychological space is what makes up the transactional distance, which can be reduced through dialogue, course structure, and especially the degree of learner autonomy including learner independence and interdependence. Thus, a faculty member's role in implementing established elements of transactional distance invariably might affect course structure; may contribute to how much autonomy and control is provided to the student; and perhaps determine what is feasible for the course including activities, group collaboration, and interaction. What is possible also might be influenced by the technologies available to both students and faculty. In order to foster a viable teaching and learning environment, faculty must be 
provided the necessary tools including learning management system and other web-based resources from which online courses can be built and delivered to students.

\section{Empirical Studies Relating to Transactional Distance Theory (TDT)}

There have been considerable interest and effort made in educational research to understand the theory of transactional distance in online learning as means of dealing with issues that relate to online course design, implementation, and engagement of students to mirror what is available in a classroom. Perhaps with this understanding, instructors and those in charge of course design and its implementation can use the knowledge gathered to enhance and develop effective online courses. Following are some of the studies that have been done to help clarify and identify the elements of transactional distance theory.

Saba and Shearer (1994) used system dynamics and integrated data, voice, and video workstations with each of the 30 learners interacting one at a time with the same instructor to establish and model the four types of interaction (direct, indirect, active, and passive) between teachers and students commonly found in distance learning, which affect the level of transactional distance for each student. By analyzing only audio communication between an individual student and the instructor using discourse analysis to arrange and sort discussions, they modeled the nodes as dialogue and structure while keeping the other factors constant. Based on these types of interactions, they concluded that it is the amount of transaction between students and teachers that determines the effectiveness of instruction, and not distance. Saba and Shearer found:

Transactional distance varied according to the rate of dialogue and structure. An increase in the level of learner control increased the rate of dialogue, which in 
turn decreased the level of transactional distance; an increase in the level of instructor control increased the rate of structure, which in turn increased the level of transactional distance. (p. 54)

However, their analysis did not include learner to learner interaction, commonly available now in most web-based distance education courses.

Bischoff, Bisconer, Kooker, and Woods (1996) used factor analysis and an researcher created survey instrument concerning elements of transactional distance such as structure and dialogue and the use of electronic e-mail with 221 graduate students in 13 public health and nursing interactive television-based courses at the University of Hawaii at Manoa. They found that dialogue was greater in distance courses than in traditional courses, but no significant difference was found on amount of structure and transactional distance between traditional and distance based courses. Bischoff et al. (1996) stated, "Within the research literature there is support for identifying elements of transactional distance and more fully developing an understanding of what behaviors on the part of teachers and students influence dialogue, structure and transactional distance" (p. 7). They also found that the use of electronic e-mail appeared to enhance communication thus lowering transactional distance, but the use of e-mail in that study varied considerable from home submission to collaborative class projects. They concluded that "Dialogue, structure and transactional distance are elements of any educational course, regardless of delivery format" (p. 17).

Chen and Willits (1998), in a quest for empirical evidence to support transactional distance theory, investigated the learning experiences of 121 learners in a videoconferencing course, using path analysis to estimate the effects of dialogue, 
structure, learner autonomy, and transactional distance on learning outcomes. While they did not find a direct relationship between learner autonomy and structure, they found that partial relationships exist between the elements of transactional distance theory with regards to student perception of how much they actually learned.

Lally and Barret (1999) investigated how computer mediated communication can be used to reduce transactional distance for 16 postgraduate students and their eight personal tutors in distance learning contexts by examining the element, structure, and dialogue. Figure 1 shows transactional distance determining variables.

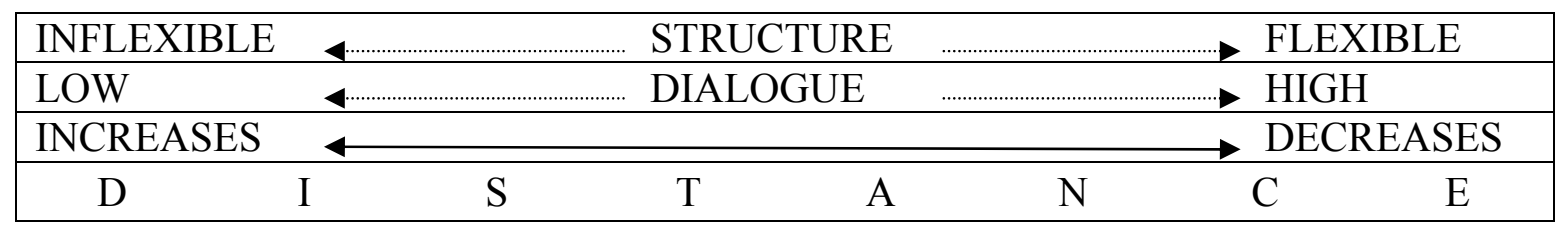

Figure 1. 'Transactional distance': Distance - determining variables (Lally \& Barret, 1999).

Lally and Barret (1999) found that computer mediated communication can support building an online learning community that is capable of supporting both academic and social support for students. They also suggested that a cooperative goal structure might be more conducive for online learning through democratization of learning than an individualized goal often associated with independent studies.

Jung (2001), using a critical review of literature, investigated theoretical applications of transactional distance theory in an effort to offer more insight on pedagogical elements of web-based education in the context of distance learning. Based on this review, he found that the web provided great structural flexibility in meeting learning needs of learners and, with proper instructor use, can contribute to the web's 
ability to deliver online courses effectively. He found that underlying the structural flexibility in most web-based courses is the use of hyperlinks technology, which can enable content expansion and adaptability with potentials that can be influenced by visual design of the delivery system. He stated that many studies found that the use of social and collaborative forms of communication increased student satisfaction and level of autonomy because of the flexible learning environment enabled by various technologies, thus lowering transactional distance for learners.

Using a 5-point Likert-scale questionnaire developed by the researcher and exploratory factor analysis in a graduate level course taught by one instructor but provided to 71 learners in three other universities located at difference areas in Taiwan in Spring of 2000, using an Integrated Learning systems with the WorldWideWeb to control the teacher, the content and web platform variables, Chen (2001) established that transactional distance consisted of four dimensions, instructor-learner, learner-learner, learner-content, and learner-interface. But Chen cautioned that these relationships are complex and needs further investigation to understand if there are other variables that are involved especially psychological and pedagogical variables that might contribute to persistence, academic success and learning outcomes for students. According to Chen, the complex nature of transactional distance found in her "analysis is important for understanding and extending Moore's Theory of Transactional Distance and for suggesting new avenues of research concerning teaching and learning environment, particularly" (p. 469) for online web-based courses.

Seung (2005) used a case study with 18 students to investigate how patterns of interaction were used to build shared knowledge in an online learning environment, 
especially when looking at student to student and student to instructor interaction through multiple communication tools such as threaded discussion, e-mail, and online chat. By assigning students to take on the role of facilitator for online class discussions, he was able to monitor and track student to student interaction and student to teacher interaction as they worked collaboratively in small groups. He concluded, "Therefore, to produce the successful learning outcomes in online courses, the instructor's role and quality of interaction are very important" (p. 66). For effective online courses, he listed the following attributes that should be addressed by the instructor: providing authentic assignments, timely feedback, and clear guidelines with a rich environment for interaction that will allow self-paced individualized learning. He contends that "instructors who teach online courses should promote each individual communication to build his/her own knowledge through critical judgment and to share it with others, and help students realize that interaction involves a student-centered learning, rather than teacher-centered learning" (p. 67).

\section{Interaction Affecting Transactional Distance}

In clarifying the role of instructors in online distance learning courses, Easton (2003) contended, "The online instructor's role, although similar to those of face-to-face instructor's, does require a paradigm shift regarding instructional time and space, virtual management techniques, and the ability to engage students through virtual communication" (p. 87). He also stated, "One common fallacy is that teaching online simply means putting up a website or turning one's lectures into text and then stepping back" (p. 89). Schrum (1998) cautioned that the designer of an online course really should consider redesigning or creating a new course when transferring an existing 
course to the web, stating "but it is unwise to simply transfer an old course to this new medium" (p. 3). According to Crumpacker (2001), Easton (2003), and Schrum (1998), creating effective online teaching requires instructors to have good presentation skills, some technical competencies, virtual management techniques, and designing instructions in conversational tones to consciously ensure immediacy and elicit positive and high order thinking from learners, thus providing for actions that will promote active and independent learning. Huang (2002) confirmed that students with more computer skills tend to have more learner autonomy and are more comfortable working with interface delivery system, both necessary factors for success in distance learning, which Chen (2001) also supported in her empirical study of transactional distance theory. Can the same also be applicable to instructors? Another interesting question that seems to resonate in most of the studies reviewed is whether providing faculty and instructor training before they are allowed to teach distance based courses might be helpful to those who may not be proficient in technology integration. Do instructors with more computer skills tend to provide more flexibility in their online course structure and delivery options that might increase dialogue and reduce transactional distance for learners?

While it makes sense to believe that most students especially the younger ones are more equipped than older students to use technology, most institutions are being forced to respond to the demands of these older students. In addition, technology seems to have all the positive elements that might contribute more to student success. Digital technology can be used to address various learning styles, achieve more individualized instruction that is self-paced for each student, and structure complete mastery modules that lend themselves to the benefit of the older and more mature students as well. As a tool, it 
allows faculty creativity in instructional designs; it can provide latitude for collaboration and various opportunities for group and team work using varied communication strategies, synchronous or asynchronous as the case may be, to address learning and teaching needs for both students and faculty. With technology, the concept of one size fits all does not apply as each student brings a different background with varied experience and ability of adapting to instruction. Thus, the importance of faculty ability to use technology to address these varied student needs perhaps may reduce transactional distance for students and be able to reach all students and improve course completion rate. Technology, when used effectively, can address these varying needs of both faculty and students thus reducing transactional distance. Instruction easily can be tailored and adapted for each student's academic need with greater control given to the students in making personal decisions that will affect course completion rate. Facilitation of learning becomes central to the faculty member's role as students are given more control in selecting and determining what they know, what they want to know and, in some cases also the best way for them to learn what they need to learn. Chen (2001) depicted the structure and elements at play in a web-based learning environment as shown in Figure 2.

In order to promote interaction and reduce transactional distance, each of the above elements as outlined by Chen (2001) need to be examined more closely. She contended, "transactional distance perceived by learners is a combination of four essential dimensions: learner-instructor, learner-learner, learner-content, and learnerinterface" (p. 462). Thus, how faculty perceives these dimensions and elements of transactional distance theory based on their philosophical inclinations might influence how they design, implement, and address the needs of their online students. The level of 


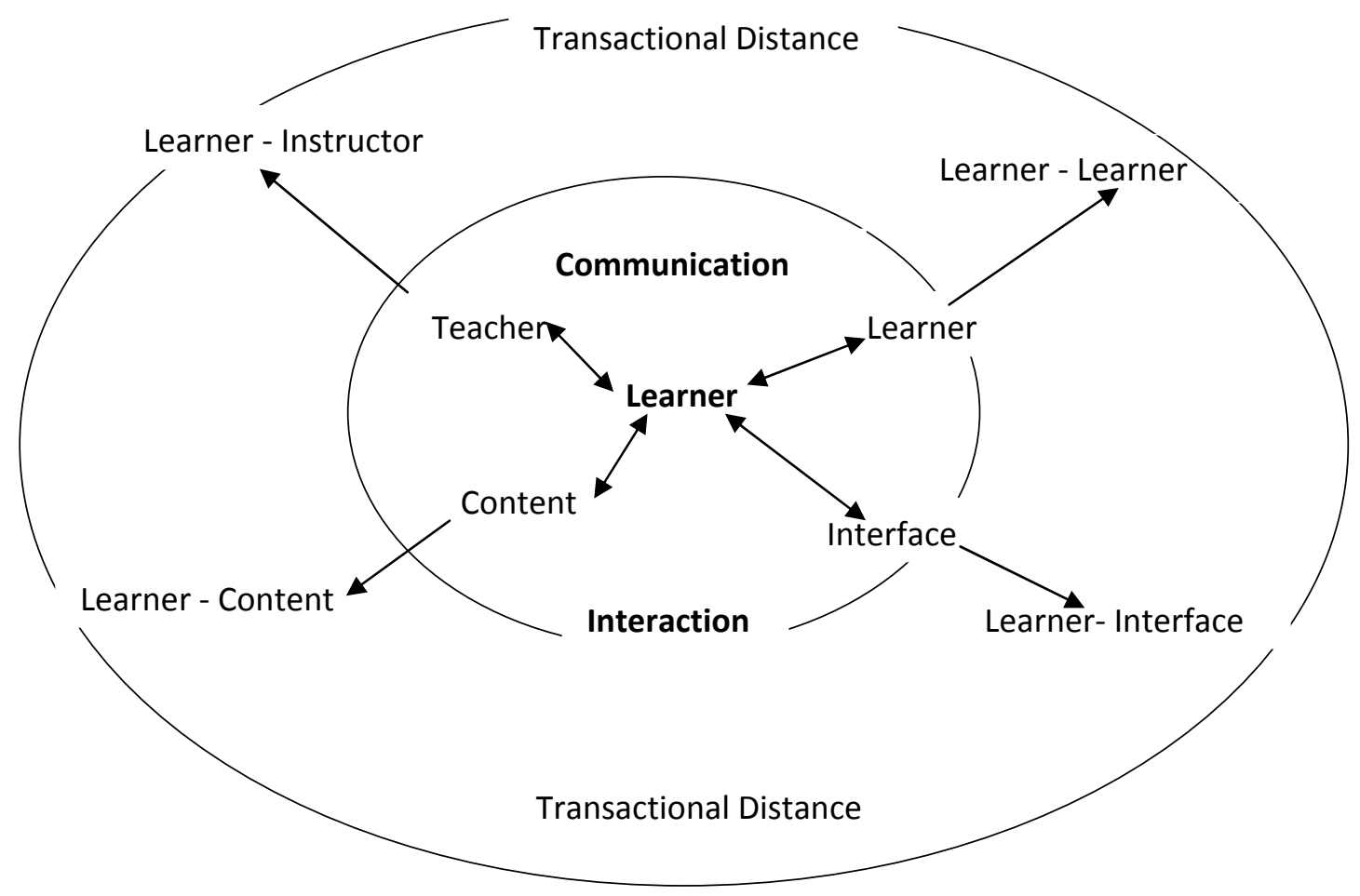

Figure 2. Transactional distance and typology of interaction in distance learning environments (Chen, 2001).

transactional distance in an online course may affect student level of interaction with regard to the instructor, other learners, course content, learning management interface, and level of control and autonomy available to students.

\section{Learner-Instructor Interaction}

Chen (2001) stated, "Learner-instructor transactional distance involves the psychological distance of understandings and communication that learners perceive as they interact with teacher" (p. 462). By virtue of selecting teaching and learning tools and deciding on course structure, instructors can influence student perception of their presence and ability to provide assistance and guidance when needed by the students. 
Benson and Samarawickrema (2009) noted, “Teachers' contextual influences and conceptions of learning also affect the learning context that they design for their students" (p. 7). According to Garrison, Anderson, and Archer (2001), appropriate communication technologies can be used successfully to create the cognitive presence needed to promote social learning in an online course for both students and for the faculty as a facilitator. Shin (2004) found that students who were more "active in logging in to their course web site tended to report greater gains from the course than students less active in the same course" (p. 284). According to Moore (1993), the "teaching philosophy, design of the course, and psychological characteristics of the instructor can influence course structure" (p. 23). He noted that high structure and high dialogue can reduce transactional distance depending on the extent of learner autonomy, which is the extent to which the learner is allowed have input on setting learning goals and selecting learning objectives for the course.

However, most research in distance education has concentrated mostly on student outcomes, level of satisfaction, and their perceptions of elements of transactional distance, often times without input from the course instructor (Benson et al.,2005; Shin, 2004; Stein, Wanstreet, Calvin, Overtoom, \& Wheaton, 2005; Wilkes, Simon, \& Brooks, 2006). Thus, there is a need to understand how instructor related actions can have an effect on the degree of transactional distance for students and how this might relate to course completion rates, especially for online web-based courses.

\section{Learner-Learner Interaction}

One of the major difficulties in online learning is how to replicate the student to student interaction found in face-to-face classes and to encourage students to learn 
together by working collaboratively on various class projects, thus lowering transactional distance for learners. When students work collaboratively, there is a tendency for increased social learning, more engagement, increased interaction with both content, interface, and other elements, which promotes constructivist learning. According to (Benard et al., 2009), learner-learner interaction promotes cognition and motivation and "is at the heart of notions about constructivist learning environment in distance learning" (p. 1248).

Instructors do influence the extent of learner to learner interaction, especially in an online course, by the nature and level of learning activities available to students in a course delivery format. The course instructor can determine what types of communications, synchronous or asynchronous, will be effective in promoting various teaching and learning activities appropriate for a course. The authentic nature and types of communications or collaborative activities and discussions allowed and encouraged within a course will depend, to a great extent, on the philosophical orientation of the instructor and course designers. The extent of these provisions, for instance whether they are required of students, within a course can directly affect the level of transactional distance each student will experience in a course and ultimately can impact student course completion. According to Benard et al. (2009), when online course designers include interactive media and allow various communications strategies it tends to promote increased student performance in a course.

The phenomenal growth of distance education has generated an unprecedented ownership and adoption of learning management systems by most colleges and universities. Oftentimes, online course design and structure are directly affected by the 
elements and features available in these learning management systems. As noted by Benson and Samarawickrema (2009), "The teaching institution also has a dominant contextual influence on learning, determining e-learning policies, infrastructure, systems and procedures that impact directly on student support" (p. 7). Instructors can influence the extent to which a learning management system will affect course design, what is provided to students in a course, and, to some extent, how other technologies are incorporated within the course.

\section{Learner - Content Interaction}

Learner - content interaction is the fundamental essence of distance learning. Learner to content interaction deals with how a learner should interact with content to formulate and construct their own meaning and understanding of the subject matter. It includes various means (i.e., text, audio, video, graphics, animation, simulations, etc.) of delivering content to the learner at the appropriate level to help the learner to understand the subject matter. Instructors can influence the pedagogical content through decisions they make about such things as feedback, discussions, whether to use synchronous or asynchronous communication, and to what extent students are allowed to interact with the content in order to reduce the amount of transactional distance for students.

\section{Experience and Sex of Faculty Member}

Given the continuing growth of online courses, there is an equally increasing growth in number of faculty who are transition from teaching face-to-face to doing the same online. In most cases, depending on institutional training and support some faculty members may find it difficult to adapt their face-to-face methods of teaching into what is 
required to become an effective online teacher as they transition to becoming more of a facilitator.

Ou (2010) used confirmatory factory analysis through a system developed by Educational Testing Service (ETS) to collect students' faculty evaluations from March 2009 to September 2010 from a large convenient sample of 11,351 students taught by 1,522 faculty members in 29 colleges and universities in 11 states. Ou stated that "research has reached a conclusion on the impact of commonly investigated factors on student evaluation such as gender, class status and class size" (p. 479) but found that “different from findings reported in previous studies, gender and class size in general does not significantly impact student rating” (p. 483) of an instructor. Accordingly, some of these instructor characteristics might relate to how faculty orchestrate and conduct online courses that might, according to the theory of transactional distance, relate to online course delivery and completion course rates.

Likewise, Robinia and Anderson (2010) studied how faculty teaching experience and preparatory experience relate to online teaching in student engagement, instructional strategies, classroom management, and use of computers. The study used the 32 -item Michigan Nurse Educators Sense of Efficacy Online Teaching instrument to collect data from 140 nurse educators through a web-based survey. Their study also looked at years of experience teaching nursing and at those who had participated in formal preparatory courses in teaching online. They used factor analysis to analyze their data and found that "there is a positive relationship between the number of online teaching experiences and increased self-efficacy for online teaching" (p. 173). Therefore, it seems that as the number of faculty continue to teach online, they also continue to build experience that 
will be used in structuring the next course and in making it more engaging for students as they develop avenues of reaching their students.

\section{Summary of Literature Review}

Based on the review of current literature, it seems that there is a critical need for more empirical understanding of the implementation of elements of transactional distance theory, especially from instructors who are involved directly in delivering online courses and can influence the amount and degree of transactional distance that students will need to overcome in order to complete their online courses successfully.

The question of higher attrition rate for distance education has been addressed (Natvig, 2007; Oblender, 2002; Park and Choi, 2009; Rovai, 2003), but gaps remain in the literature on how best to address this higher rate pedagogically by online course instructors. Moore's (1993) theory of transactional distance contains essential elements (dialogue, structure, and learner autonomy) that, when orchestrated and implemented consistently, might affect course completion rate by students. Lally and Barret (1999) found that computer mediated communication can support building online learning communities supporting both social and academic integration and also can contribute to reducing transactional distance and increasing online course completion rates. Various studies related to transactional distance theory (Bischoff, Bisconer, Kooker, \& Wood, 1996; Chen, 2001; Jung, 2001; Saba \& Shearer, 1994; Seung, 2005), although based mostly on student forms of interaction, tend to show that when there is and increase in dialogue, with loose structure and high learner autonomy, there seems to be reduced transactional distance for students, which might increase the online course completion rate for students. 
Based on the literature review, it is evident that most studies relating to transactional distance theory tend to focus more on student course satisfaction, perception, and completion rates, with little emphasis on instructor role, perceptions, and their implementation of the elements of transactional distance theory. Given the essential role instructors play in course delivery, there is an urgent need to explore how their actions and inactions might relate to course outcomes. The purpose of this study was to determine how faculty perceptions and implementation of elements of transactional distance theory correlate with course completion rates for online web based courses. Data gathered from this study will add to the body of literature about transactional distance theory and online course completion rates. 


\section{CHAPTER III}

\section{METHODS}

The main purpose of this study was to investigate the relationships between faculty perceptions and self-reported implementation of elements of transactional distance theory and online course completion rates. As noted earlier, Moore $(1973,1983)$ defined transactional distance as "a psychological space of potential misunderstandings, between behaviors of instructors and those of the learners" (cited in Moore \& Kearsley, 1996, p. 200) and asserted that greater transactional distance in a course is related to higher dropout rates, especially in online courses.

Thus, an investigation of faculty perceptions and implementation of elements of transactional distance theory could lead to a better understanding of how faculty pedagogical roles in structuring and teaching courses online may reduce transactional distance and enhance course completion rates for students. In addition, understanding how faculty roles relate to transactional distance for students as applied to online courses will help in extending and strengthening Michael Moore's (1993) original transactional distance theory developed for video and audio correspondence courses to online webbased courses. In order to lower transactional distance for online students, institutions may need to become more active in providing conducive teaching and learning environments where faculty can take more control of nurturing and responding to the unique and individual needs of the online students to enable them to complete their online courses successfully and to reduce the higher than usual withdrawal rates that constantly are being reported for online based courses. 
The purpose of this study was to answer the following research questions:

1. What are online instructors' perceptions of elements of transactional distance theory?

2. Is there a relationship between faculty self-reported implementation of elements of transactional distance theory in their online courses with regard to faculty sex?

3. Is there a relationship between faculty self-reported implementation of elements of transactional distance theory in their online courses and their number of years teaching online?

4. Is there a relationship between faculty perceptions and their self-reported implementations of elements of transactional distance theory and student online course completion rates?

The first research question was designed to provide insight on instructors' perceptions of the elements of transactional distance theory. Elements previously identified included dialogue, course structure, learner autonomy, and technology interface in an online course (Chen \& Willits, 1998). Dialogue included various forms of interaction including student to instructor, student to student, and student to content.

The second research question was designed to provide insight into how faculty implementation of the elements of transactional distance theory may be related to faculty member sex.

The third research question was designed to provide insight into how faculty implementation of the elements of transactional distance theory is related to faculty years of experience teaching online at the college level. 
The fourth research question examined the relationship between student course completion rate and instructor self-reported implementation of elements of transactional distance theory. In other words, are there certain actions and pedagogical inclinations that might relate to decreasing transactional distance for students who are enrolled in online courses? According to Cain and Pitre (2008), the use of computer mediated conferencing tools seems to contribute to student learning by lowering the levels of transactional distance for students enrolled in an online course.

\section{Participants and Sampling}

The target population for this study was faculty members who teach online webbased distance learning courses in colleges. The sample consisted of responses from college faculty members who had taught at least one online web-based course at either of two major colleges in the southeastern United States and who had agreed to participate in the study by completing an online survey. These two colleges were selected because they "rank as the first and tenth largest colleges in the United States, serving a population of diverse students, with a diverse faculty, and in a state, Florida, which is highly involved with distance education" (Hernandez, 2008, p. 95). According to Cohen (1988) and GPower software v3.11, a sample size of 200 would be sufficient to obtain about $80 \%$ power in an analysis of variance for a medium effect size of $f=.25$ using $\alpha=.05$.

\section{The Data Collecting Instrument}

Other researchers such as Chen (2001), Zhang (2003), and Rabinovich (2009) have developed and used instruments to study student perceptions of the elements of transactional distance theory in web-based online courses. The researcher modified selected items on such previously reported research studies to reflect faculty perceptions 
and self-reported implementation of the elements of transactional distance theory. The online survey instrument developed for this study included questions that pertain to the elements of transactional distance theory and some items designed to gather faculty demographic data including age, sex, and years of experience teaching online and faceto-face. The selected items were modified to meet the unique needs of this study with focus on faculty perceptions and self-reported implementations of the elements of transactional distance theory. The final stage of re-structuring the questions included a review and an approval by three faculty members who teach online and who also critiqued the survey for relevance to faculty implementation of an online course. At least one of these individuals felt that six initial questions were not clear. Upon consultation with the researcher's major professor, four of these questions were eliminated from the survey and two were reworded and retained. The resulting version of the instrument was reviewed and approved by the same faculty members.

\section{Instrument Validation}

Based on an initial test of structure, an exploratory factor analysis was used in place of the proposed confirmatory factor analysis to determine the factors that make up transactional distance theory. A summary of participants' responses was calculated for each of the questions and analyzed, as presented in Chapter 4.

\section{Instrument Description}

The survey instrument asked faculty participants to select one specific course that they had taught online and then base their responses to the survey questions only on the reference course. They were required to provide number of enrolled students for the course and the number of students who completed the course. 
The survey used 4-point Likert scale statements to probe instructor perceptions of the structure and characteristics of the online course. There were questions about how often they performed such activities as course announcements, discussions, providing feedback to students, encouraging students to stay on task, and providing opportunities for students to engage in collaborative assignments.

In addition to those questions related to faculty perceptions to their selected online course, a section of the instrument collected demographic information on participant sex, number of years of experience in teaching both face-to-face and online courses, and instructional practices as well (Appendix A).

\section{Data Collection Procedures}

Prior to the study and data collection, a proposal was sent to the Institutional Review Board (IRB) at Florida International University for approval to collect data from human subjects. After approval was obtained from the IRB, the researcher also applied for and obtained approval to collect data from both colleges. The IRB request for this study was approved under the "exempt" category. Participants were informed that participation was voluntary and that collected data would be reported in aggregate format, thereby protecting the identities of individual respondents.

As part of the approval process in both colleges, the researcher also requested and was provided with a list of instructors who had taught online courses for each of the colleges within the past two years; this group was the target group for the survey. The researcher worked with the institutional representative to send a pre-notification to the selected faculty, encouraging them to expect an online survey from the researcher and to complete it as soon as they could. This helped to avoid the survey being grouped or 
categorized as junk mails by the instructors. This action might have contributed to the $65.17 \%$ response rate for the online survey.

Qualtrics, the online survey program used for the survey data collection, has builtin features for tracking and keeping records of those who completed the survey, thus allowing follow-up e-mails to be targeted to those who did not respond to the survey. Sending e-mails to only those who had not responded to the survey might have contributed to easier follow-ups. Both institutions allowed the researcher to up to three attempts to solicit survey completion from the faculty. All completed surveys were recorded and stored by Qualtrics.

\section{Research Design}

This was an ex post facto study that used exploratory factor analysis and other correlation statistics to analyze collected data. Correlational statistics were used to determine degree of relationships between transactional distance theory elements and faculty members' number of years teaching online, sex of faculty members, and online course completion rates.

\section{Data Analysis}

Descriptive and frequency statistics were presented for sex and years of online teaching experience. Descriptive statistics such as means and standard deviation were computed for common variables such as faculty number of years teaching online, etc.

The predictor variables of this study are faculty self-reported perceptions of elements of transactional distance theory in online courses. Faculty perceptions of the elements of transactional distance theory were calculated for each component, including instructor interface, learner-learner interaction, instructor-learner interaction, learner 
autonomy, and higher learner expectation. Since questions were taken from previous research studies on transactional distance, a confirmatory factory analysis was chosen as a means to validate the survey instrument. Exploratory factor analysis has been used in various studies to estimate the construct validity of an instrument. Rao and Sachs (1999) used confirmatory factor analysis to examine factors related to motivation and selfregulated learning strategies used by Chinese secondary school students. Black and McCoach (2008) used confirmatory factor analysis to compare the "adequacy and fit" of structural models in an attempt to reduce the number of items used in predicting learning styles. As stated by Roberts (1999), confirmatory factor analysis is particularly useful when the researcher has an understanding of the construct underlying the data instead of exploratory factor analysis where data can be analyzed without fundamental knowledge of the constructs of the data. Roberts encourages the use of confirmatory factor analysis by stating that "it is a way to test the priori expectations of the researcher, encouraging more meaningful and empirically based research" (48).

\section{Research Question \#1}

Research question \#1 was answered by summing the scores of respondents for each of the factors in the transactional distance survey and describing them, using various descriptive statistics including means and standard deviations.

\section{Research Question \#2}

Research question \#2 was answered using multivariate analysis of variance to determine if there is a significant difference between male and female instructors of distance learning courses on the whole transactional distance survey and on each of the factors that make up the instrument. According to Stevens (1990), it is important to first 
demonstrate overall significance to determine if further analysis is needed. This was done and univariate ANOVAs were performed for each of the factors. To control for the probability of a Type I error, Holm's sequential Bonferroni procedure was used.

\section{Research Question \#3}

Research question \#3 was answered using multivariate analysis of variance to determine if there is a significant difference between faculty years of teaching online and on each of the factors that make up the instrument. Univariate ANOVAs were performed for each of the factors. Holm's sequential Bonferroni procedure was applied to control for the probability of Type I error.

\section{Research Question \#4}

Research question \#4 was answered by using multiple linear regression, with the course passing rate as the criterion variable and the total scores of the instructor on the factors of the transactional distance survey. SPSS for Windows (v.18) was used for statistical analyses. Tests were deemed significant at $p<.05$.

\section{Summary}

This chapter consisted of methods and analysis that were employed to investigate and answer the research questions related to transactional distance theory as presented in Chapter 1. The chapter presented the data collection method, procedures for protection of human subjects, detailed explanations of measurement instrument, and how each element of transactional distance theory was calculated and used in data analysis.

The survey instrument was administered through an online system that was emailed to a select group of faculty who teach online at two prominent colleges in the southeastern part of the United States. Descriptive statistics, multivariate analysis, factor 
analysis, and linear regression were used to analyze and report collected data. Results of the data analysis are presented in Chapter 4 and discussed in Chapter 5.

\section{CHAPTER IV}

\section{DATA ANALYSIS AND FINDINGS}

This chapter provides and presents the results of quantitative analysis of this research. First a descriptive summary of survey participants is provided, along with survey completion rates for both institutions that were involved in the study. Overall completion rate for data collection is presented, followed by a breakdown of institutional participants and a summary of their demographic information. An exploratory factor analysis was used to determine the elements of transactional distance theory. Finally, multiple regression analysis was used to test whether faculty perceptions of the elements of transactional distance theory as a measure with research instrument related to student online course completion rate.

\section{Summary of Survey Response Rate}

This research study surveyed faculty who teach online at two large colleges in southeastern United States. The researcher worked with both institutions in obtaining a list of both part-time and full-time faculty members who teach online courses. An online web-based survey program, Qualtrics, was used for the online survey administration, data collection, and follow-ups. In addition to providing the mailing list of faculty who teach online, both institutions granted the researcher three attempts to solicit and request survey completion from faculty who had not completed or responded to the survey. One of the useful features provided by the online survey program was the ability to track survey 
completion using the respondent's e-mail address. This feature allowed unique e-mail follow-ups directed only to those who had not completed the survey or had not

responded, helping to minimize unnecessary waste of time for those who responded to the survey and to increase completion rate.

To increase survey completion rate in both institutions, the researcher worked with the respective representative of the college in charge of working with faculty who teach online to send an e-mail to alert faculty of the survey and to urge them to help complete the survey as soon as they could. Shannon and Bradshaw (2002) found that when using electronic mail for a survey, "Sending a pre-notification e-mail to respondents is very beneficial, especially in reducing respondents' perception of being spammed with unsolicited e-mail" (p. 190). This process also helped to verify e-mail addresses and ensured e-mails were delivered to the intended respondents.

Subsequent requests also were e-mailed to faculty to urge them to complete the survey. There usually was an increase of respondents after such requests were made, especially from their school's officials. During data collection, only six respondents emailed the researcher about having a problem entering numbers in the survey. The survey program has error checking for numbers and will not allow submission with invalid characters or letters; once those who called or e-mailed the researcher entered valid numbers, they were able to go back to the survey. The error checking feature in the survey also helped to reduce survey errors and incomplete surveys, but also may have contributed to some of the respondents not completing the survey as some may not have continued with the survey but never tried to report such errors to the researcher. 


\section{Survey Response Rate}

Data from the institutions were collected in Fall semester (institution A) and Spring semester (institution B) of the 2011- 2012 academic year, respectively. For both institutions, a total of 534 faculty members were e-mailed the link to complete the online survey and a total of 348 faculty members completed the survey, a response rate of $65.17 \%(n=348,65.17 \%)$. A breakdown of the response rate for each institution is provided, but data analysis for both institutions will be provided jointly and differences will be noted when appropriate.

For institution A, a total of 226 faculty members who teach online courses at the college were e-mailed; 142 completed the online survey for a response rate of $62.8 \%$ $(n=142,62.8 \%)$. For institution B, a total of 308 faculty members who teach online were e-mailed the survey link; a total of 206 completed the survey for a response rate of $66.88 \%(n=206,66.88 \%)$.

\section{Descriptive Analysis}

SPSS Version 20.0 was used to analyze collected data from the online survey program. Data from the online survey were downloaded and imported into SPSS and examined for accuracy and incomplete and missing data were noted. Twelve participants who did not complete their survey correctly and had a significant amount of missing data were removed from the survey. Questionnaire items written in reserve order direction were reverse scored and missing values were replaced with the mean value of each, where applicable.

For those who completed the online survey, Table 1 shows the distribution of faculty members' sex at both institutions. A slightly higher number of women completed 
the survey as compared to men. The sample is a good representation of faculty sex distribution in most colleges, which closely resembles that of the faculty who also teach online as well. According to Hagedorn and Laden (2002), women's representation is significantly larger at colleges (48.7\%) when compared to universities (36.3\%). 
Table 1

Sex Distribution for Survey Participants for Both Institutions

\begin{tabular}{lrc}
\hline \multicolumn{1}{c}{ Sex } & Number & Percent \\
\hline Male & 158 & 45.40 \\
Female & 189 & 54.31 \\
Did not respond & 1 & .29 \\
Total & 348 & 100.00 \\
\hline
\end{tabular}

Table 2 shows the distribution of faculty who designed and developed their online courses. In some institutions, course development teams may be different from online course delivery faculty. Perhaps those who designed and developed their own course may be better able to deliver those courses by using their appropriate technology to implement the delivery of the course as they planned. Some institutions have extensive and structured course development with professional instructional technology developers and designers who assist faculty in designing and developing online master courses that then are assigned to faculty members to teach. In other institutions, faculty are allowed to design and develop their own online course with or without the help of these professional instructional designers. As part of the survey, participants were asked to indicate if they designed and developed their selected online course for the survey. As shown in Table 2, a higher percentage of faculty members selected for this study designed and developed their online course $(50.00 \%)$, compared to those who did not develop their online course $(48.85 \%)$ and those who did not respond to this question $(1.14 \%)$. 
Table 2

Faculty Course Design and Development

\begin{tabular}{ccc}
\hline Designed Their Online Course & Number & Percent \\
\hline Yes & 174 & 50.00 \\
No & 170 & 48.85 \\
Did not respond & 4 & 1.15 \\
Total & 348 & 100.00 \\
\hline
\end{tabular}

\section{Data Gathering Instrument}

Exploratory factor analysis using a principal component extraction with a varimax rotation revealed a six factor solution, which accounted for slightly over $65 \%$ of the variance of the entire transactional distance theory scores as measured by the survey instrument. It should be noted that proposed confirmatory factory analysis showed that the proposed four factor solution did not provide a good match for the data, so an exploratory factor analysis was carried out that revealed six factors. These six factors were:

- Instructor Interface

- Learner-Learner Interaction

- Course Structure

- Instructor-Learner Interaction

- Learner Autonomy

- Higher Learner Expectation 
Using Mplus, the six factors were modeled in a confirmatory factor analysis and compared to a four factor model. The six factor model fit significantly better than the four factor model, $\chi^{2}(15, N=318)=1057.20, p<.001$. Therefore, to answer the research questions, these six factors were used. Table 3 contains a partial listing of the three items loading highest on each factor. (For a complete list of item loading in the six factors of the transactional distance attitude survey see Appendix B.)

\section{Results of Research Question \#1}

Research question \#1: What are online instructors' perceptions of the elements of transactional distance theory?

A measure of participant responses to each factor was obtained first by determining the scores for each factor. This was done by adding the responses for each item loading on that factor on a scale where 1 represented the lowest score on the level of use of transactional distance theory and 4 represented the highest score on the level of use of transactional distance theory, as measured by the survey instrument. Then the highest possible level of the use of transactional distance theory for each factor was determined by multiplying the number of items loading on a factor by 4 , the highest possible score for each item. Adding the actual sum of the factor item scores and dividing it by the highest possible score for each factor determined the level of use of the theory. The level obtained can be conceived of as the percent of the highest possible score obtained for each factor. Table 4 indicates the factor percentage scores for each of the six factors. 


\section{Table 3}

Top Three Loading of Items in Each of the Six Factors of Transactional Distance Attitude Survey

\begin{tabular}{|c|c|c|c|c|c|c|}
\hline \multirow[t]{2}{*}{ Item } & \multicolumn{6}{|c|}{ Loadings } \\
\hline & $\begin{array}{l}\text { Instructor } \\
\text { Interface }\end{array}$ & $\begin{array}{l}\text { Learner- } \\
\text { Learner } \\
\text { Interaction }\end{array}$ & $\begin{array}{l}\text { Course } \\
\text { Structure }\end{array}$ & $\begin{array}{l}\text { Instructor- } \\
\text { Learner } \\
\text { Interaction }\end{array}$ & $\begin{array}{l}\text { Learner } \\
\text { Autonomy }\end{array}$ & $\begin{array}{c}\text { Higher } \\
\text { Learner } \\
\text { Expectation }\end{array}$ \\
\hline $\begin{array}{l}\text { Our learning management system enables me to } \\
\text { manage all aspects of my on-line course in an } \\
\text { efficient way. }\end{array}$ & .840 & .187 & .058 & .088 & .044 & .117 \\
\hline $\begin{array}{l}\text { Our learning management system provides a } \\
\text { good teaching environment for me. }\end{array}$ & .811 & .271 & .106 & .155 & .206 & .098 \\
\hline $\begin{array}{l}\text { Our learning management system enhances my } \\
\text { on-line teaching. }\end{array}$ & .806 & .221 & .137 & .180 & .221 & .043 \\
\hline $\begin{array}{l}\text { Critique fellow student's work before that work } \\
\text { is turned in for your grading. }\end{array}$ & .224 & .781 & -.080 & .082 & -.020 & -.044 \\
\hline $\begin{array}{l}\text { I spend too much time trying to use our learning } \\
\text { management system to help my students. }\end{array}$ & .140 & .777 & -.103 & -.109 & .076 & .178 \\
\hline $\begin{array}{l}\text { Students should summarize group threaded } \\
\text { discussions before adding their own comments. }\end{array}$ & .175 & .706 & .282 & .154 & .264 & .004 \\
\hline $\begin{array}{l}\text { Students should have access to on-line } \\
\text { management system } 24 / 7 \text {. }\end{array}$ & .214 & -.037 & .735 & .271 & .326 & .149 \\
\hline $\begin{array}{l}\text { Students should apply what they are learning to } \\
\text { real world situations. }\end{array}$ & .261 & .092 & .710 & .195 & .276 & .042 \\
\hline $\begin{array}{l}\text { All students must turn in assignments using } \\
\text { specific format. }\end{array}$ & .243 & .197 & .649 & .178 & .044 & .350 \\
\hline $\begin{array}{l}\text { Encourage your students to ask questions about } \\
\text { course material. }\end{array}$ & .223 & -.025 & .149 & .780 & .045 & .110 \\
\hline $\begin{array}{l}\text { Make course announcements to students in this } \\
\text { course. }\end{array}$ & .076 & .020 & .366 & .611 & .191 & .054 \\
\hline
\end{tabular}




\section{Table 3}

Top Three Loading of Items in Each of the Six Factors of Transactional Distance Attitude Survey

\begin{tabular}{|c|c|c|c|c|c|c|}
\hline \multirow[t]{2}{*}{ Item } & \multicolumn{6}{|c|}{ Loadings } \\
\hline & $\begin{array}{l}\text { Instructor } \\
\text { Interface }\end{array}$ & $\begin{array}{l}\text { Learner- } \\
\text { Learner } \\
\text { Interaction }\end{array}$ & $\begin{array}{l}\text { Course } \\
\text { Structure }\end{array}$ & $\begin{array}{l}\text { Instructor- } \\
\text { Learner } \\
\text { Interaction }\end{array}$ & $\begin{array}{l}\text { Learner } \\
\text { Autonomy }\end{array}$ & $\begin{array}{l}\text { Higher } \\
\text { Learner } \\
\text { Expectation }\end{array}$ \\
\hline $\begin{array}{l}\text { Discuss comments that you made on one or more } \\
\text { assignments for your students. }\end{array}$ & .315 & .378 & .181 & .602 & -.080 & .182 \\
\hline $\begin{array}{l}\text { Having students search for answer to their } \\
\text { question rather than providing it to them or } \\
\text { having them ask other students. }\end{array}$ & .088 & .046 & .141 & -.108 & .636 & .353 \\
\hline $\begin{array}{l}\text { Encouraging students to take responsibility for } \\
\text { their learning. }\end{array}$ & .250 & .215 & .104 & .306 & .628 & .054 \\
\hline $\begin{array}{l}\text { Requiring students to complete course } \\
\text { assignments on fixed deadlines }\end{array}$ & .251 & .116 & .110 & .175 & .623 & .380 \\
\hline $\begin{array}{l}\text { Encouraging students to spend more time focused } \\
\text { on their studies. }\end{array}$ & .186 & .071 & .105 & .091 & .163 & .793 \\
\hline $\begin{array}{l}\text { Having students find additional learning } \\
\text { resources (library, on-line inks, etc.). }\end{array}$ & .105 & -.007 & .205 & .170 & .201 & .632 \\
\hline
\end{tabular}


Table 4

Factor Percentage Scores

\begin{tabular}{lcc}
\hline \multicolumn{1}{c}{ Factor } & $\begin{array}{c}\text { Percent of } \\
\text { Possible } \\
\text { Scores }\end{array}$ & Std. Deviation \\
\hline Factor 1: Instructor Interface & 76.88 & 18.05 \\
Factor 2: Learner-Learner Interaction & 67.42 & 16.70 \\
Factor 3: Course Structure & 80.02 & 16.11 \\
Factor 4: Instructor-Learner Interaction & 75.53 & 15.53 \\
Factor 5: Learner Autonomy & 59.77 & 25.35 \\
Factor 6: Higher Learner Expectation & 76.13 & 18.04 \\
\hline
\end{tabular}

The null hypothesis that the percentage scores for all six factors were equal $\left(\mathrm{H}_{0}: \mu_{1}=\mu_{2}=\right.$ $\mu_{3}=\mu_{4}=\mu_{5}=\mu_{6}$ ) was tested using a repeated measures analysis of variance. This null hypothesis was rejected, $F(5,357)=92.64, p<.001, \eta^{2}=.57$.

Post hoc comparisons using a Bonferroni adjustment indicated which pairs of factors had a different mean percent. Table 5 presents this information.

Factor 1, instructor interface, with a mean score of $76.88 \%$, might have been perceived by faculty members as critical for transactional distance because they also are expected to use it to relate to students. This factor included questions that asked faculty members to rank the importance of such questions as whether their learning management system enables them to manage all aspects of my online course in an efficient ways, and whether they are comfortable using their learning management system to fully engage 
Table 5

Results of Planned Comparisons Between Mean Percent Scores of the Six Factors

\begin{tabular}{|c|c|c|c|c|c|c|}
\hline Factor & 1 & 2 & 3 & 4 & 5 & 6 \\
\hline 1. Instructor Interface & & + & - & $=$ & + & $=$ \\
\hline 2. Learner-Learner Interaction & - & & - & - & - & - \\
\hline 3. Course Structure & + & + & & + & + & + \\
\hline 4. Instructor-Learner Interaction & $=$ & - & - & & - & $=$ \\
\hline 5. Learner Autonomy & - & - & - & - & & - \\
\hline 6. Higher Learner Expectation & $=$ & + & - & $=$ & + & \\
\hline
\end{tabular}

+ entered indicates that the mean of the row variable is greater than that of the column variable

- entered indicates that the mean of the row variable is less than the mean of the column variable

$=$ entered indicates that the means of the row and column variables are not significantly different at the .05 level of significance.

and meet the needs of online students. This factor, although not part of the original theory of transactional distance theory, may provide an understanding of how faculty perceive the importance of their interface through which they communicate and engage their students. This has a profound implication within the theory of transactional distance. Both institutions surveyed use a learning management system as their online delivery course platform. Most colleges have invested substantially on learning management systems such as ANGEL, Blackboard, Module, Desire to Learn, and Canvas, and most require all online faculty members to use such a system to support their online classes. According to Ryan, Toye, Charron, and Park (2012), most learning management systems have evolved into an effective delivery system that provides active support for 
engagement, connections between all aspects of online courses including discussion, and other course transactions, thus making them an essential aspect of distance learning.

Factor 2, learner-learner interaction, had the lower mean score $(67.42 \%)$; and it included such questions as students should summarize group threaded discussions before adding their own comments and critiquing other students work before that work is turned in for faculty members' grading. However, it should be noted that some faculty who did not create their own online course might feel that they do not have much control over how their online course is structured since it was designed for them. Only about $50 \%$ of respondents indicated that they developed their own online course, while about $48.85 \%$ did not. The low score for learner-learner interaction was surprising and contrary to transactional distance theory; perhaps it may not be as important to faculty members who teach online.

Factor 3, course structure, had a mean score of $80.02 \%$, greater than all the other factors; this indicates most faculty members perceive this as a factor that can affect transactional distance for students in their online courses. This was one of the original factors as defined by Moore (1993) and included questions such as whether it is important for students to have the same experience in an online course, and whether students should be allowed to self-select online course content.

Factor 4, instructor-learner interaction, also one of the original factors identified by Moore (1993), had a mean score of $75.44 \%$ and included questions such as whether students should have access to online management system $24 / 7$, and whether all students must turn in assignments using the specific format. This was also part of the original 
factors in Moore's transactional distance theory and seems to show that faculty members do value the need to be connected to their students.

Factor 5, learner autonomy, had a score of $59.77 \%$ and also was part of the original factors of transactional distance theory. The factor included such questions as whether to have students search for answers to their questions rather than providing answers to them, and whether to encourage them to take responsibility for their learning.

Factor 6, higher learner expectations, had a score of $76.13 \%$ and was not included in the original factors of transactional distance theory. This factor relates to learner autonomy and included such questions as whether to have students spend more time focused on their studies, and whether to have them find additional resources (library, online links, etc.) for their online course.

\section{Results of Research Question \#2}

Research Question\#2: Is there a relationship between faculty self-reported implementation of the elements of transactional distance in their online courses with regard to faculty sex.

A Pearson (2-tailed) correlation coefficient was computed to assess the relationship between faculty self-reported implementation of the elements of transactional distance in their online course with regard to faculty sex.

According to Chen (2001), how faculty perceive the elements of transactional distance based on their philosophical inclinations may influence how they design and implement their online course. Were there differences between male and female faculty and their perception of elements of transactional distance theory? 
Table 6 shows the mean scores and the standard deviation for men and women for all the factors of transactional distance theory as measured by the instrument.

Table 6

Men and Women Descriptive Scores on Elements of Transactional Distance Theory (TDT)

\begin{tabular}{lcccc}
\hline \multicolumn{1}{c}{ Factors } & \multicolumn{2}{c}{ Male $(n=159)$} & \multicolumn{2}{c}{ Female $(n=191)$} \\
& $M$ & $S D$ & $M$ & $S D$ \\
\hline Instructor Interface & 71.74 & 21.21 & 80.53 & 14.18 \\
Learner-Learner Interaction & 62.54 & 17.30 & 70.64 & 15.04 \\
Course Structure & 73.70 & 20.20 & 85.20 & 9.6 \\
Instructor-Learner Interaction & 72.75 & 20.96 & 77.15 & 8.49 \\
Learner Autonomy & 56.44 & 25.54 & 62.04 & 25.46 \\
Higher Learner Expectation & 70.91 & 21.67 & 80.69 & 13.43 \\
\hline
\end{tabular}

There were significant differences at the $\alpha=.05$ level between the mean scores of the men and women on the total score of the transactional distance on all six factors as shown in Table 6. There were significant differences between the mean scores of faculty men and women on the total scores of transactional distance TDT scale across all six factors. Based on the collected data, women consistently scored significantly higher than men in all factors of transactional distance. Thus, women $(M=80.53)$ more often perceived instructor interface as contributing to degree of transactional distance then men $(M=71.74)$. More female faculty $(M=70.64)$ perceived learner-learner interaction as contributing to levels of transactional distance in a course than men $(M=62.54)$. More 
women $(M=85.20)$ perceived course structure as contributing to levels of transactional distance than men $(M=73.70)$. More women $(M=77.15)$ perceived instructor-learner interaction as contributing to levels of transactional distance than men $(M=72.75)$. More women $(M=62.04)$ perceived learner autonomy as contributing to levels of transactional distance than men $(M=56.44)$. More women $(M=80.69)$ perceived higher learner expectation than men $(M=70.91)$ as contributing to students' levels of transactional distance in an online course.

Table 7 shows the result of differences in analysis of variance of mean factor scores by faculty sex.

\section{Results of Research Question \#3}

Research \#3: Is there a relationship between faculty self-reported implementation of elements of transactional distance theory in their online course and their number of years teaching online?

Pearson 2 tailed correlation coefficients were computed among the six transactional distance scales using the Bonferroni approach to control for Type I. The results of the correlational analysis show that all of the factors showed statistically significant correlations with number of years faculty have been teaching online at the college level. In general, the results suggest that number of years teaching online seems to correlate significantly with all the six factors (instructor interface, learner-learner interaction, course structure, instructor-learner interaction, learner autonomy, and higher learner expectation) of transactional distance theory. 
Table 7

Analysis of Variance for Differences in Mean Factor Scores by Sex

\begin{tabular}{|c|c|c|c|c|}
\hline Source & $d f$ & $F$ & $\eta$ & $p$ \\
\hline \multicolumn{5}{|l|}{ Instructor Interface } \\
\hline Sex & 1 & $21.34 * *$ & .058 & $<.001$ \\
\hline error & 348 & $(314.26)$ & & \\
\hline \multicolumn{5}{|c|}{$\underline{\text { Learner-Learner Interface }}$} \\
\hline Sex & 1 & $21.90 * *$ & .059 & $<.001$ \\
\hline error & 348 & $(259.54)$ & & \\
\hline \multicolumn{5}{|l|}{$\underline{\text { Course Structure }}$} \\
\hline Sex & 1 & $48.75 * *$ & .123 & $<.001$ \\
\hline error & 348 & $(235.66)$ & & \\
\hline \multicolumn{5}{|c|}{ Instructor-Learner Interaction } \\
\hline Sex & 1 & $7.02 * *$ & .020 & $<.008$ \\
\hline error & 348 & $(239.06)$ & & \\
\hline \multicolumn{5}{|l|}{ Learner Autonomy } \\
\hline Sex & 1 & $4.17 * *$ & .012 & $<.042$ \\
\hline error & 348 & $(650.34)$ & & \\
\hline \multicolumn{5}{|c|}{ Higher Learner Expectation } \\
\hline Sex & 1 & 26.63 & .071 & $<.001$ \\
\hline error & 348 & $(311.76)$ & & \\
\hline
\end{tabular}

Note. Values enclosed in parenthesis represent mean square errors.

$* * p<.01$

The correlation between faculty number of years teaching online courses at the college level and instructor interface was significant $[r(348)=.22, p<.001]$. The correlation between faculty number of years teaching online courses at the college level and learner-learner interaction was significant $[r(348)=.14, p<.001]$. The correlation 
between faculty number of years teaching online courses at the college level and course structure was significant $[r(348)=.25, \mathrm{p}<.001$. $]$ The correlation between faculty number of years teaching online courses at the college level and instructor-learner interaction was significant $[r(348)=.14, \mathrm{p}<.001]$. The correlation between faculty number of years teaching online courses at the college level and learner autonomy was significant $[r(348)=.14, \mathrm{p}<.001]$. The correlation between faculty number of years teaching online courses at the college level and higher learner expectation was significant $r(348)=.11, \mathrm{p}<.05$.

\section{Results of Research Question \#4}

Research Question 4: Is there a relationship between faculty members' selfreported implementations of elements of transactional distance theory and student online course completion rates? Table 8 shows the result of the regression analysis between elements of transactional distance theory and online course completion rates as measured by the research instrument.

Finally, multiple regression analysis was used to test whether faculty perception of transactional distance significantly predicted student online course completion rate. The results of the regression indicated that two of the six predictors explained only $12 \%$ of the variance $\left[R^{2}=.12, F(6,355)=7.70, p<.01\right]$. Based on the data collected and in order of importance, the factors described as significant in the transactional distance survey instrument based on the collected data were instructor interface $($ Beta $=.20)$ and instructor-learner interaction $($ Beta $=.17)$. 
Table 8

Regression Transactional Distance Theory (TDT) and Completion Rate

\begin{tabular}{llc}
\hline \multicolumn{1}{c}{ Factors } & $\beta$ & $t$ \\
\hline Instructor Interface & .20 & $2.64^{*}$ \\
Learner-Learner Interaction & .08 & .93 \\
Course Structure & -.08 & -1.01 \\
Instructor-Learner Interaction & .17 & $2.59^{*}$ \\
Learner Autonomy & -.02 & -.40 \\
Higher Learner Expectation & .05 & .87 \\
\hline
\end{tabular}

$R^{2}=.12(\mathrm{p}<.001)$

It is important to note that only two of the factors of transactional distance theory as measured with the research instrument accounted for significant proportions of the variance of the completion rate variable. The $t$ values for both factors (instructor interface and instructor-learner interaction) were significant. The other variables (learnerlearner interaction, course structure, learner autonomy and higher learner expectations) did not account for significant proportions of the variance of online completion rate. The findings suggest that faculty perceptions of instructor interface and instructor-learner interaction were significantly related to course completion rates.

The implications of the study, findings, and recommendations are presented in Chapter 5, along with recommendations for future study. 


\section{CHAPTER V}

\section{DISCUSSION, CONCLUSIONS, AND RECOMMENDATIONS}

This final chapter provides a restatement of the research problem, summarizes the methods used for data analysis, and provides results with recommendations for future studies. First, a restatement of the problem will be presented, followed by a discussion of the findings, along with limitations of the study. Then conclusions and implications for theory and practice with recommendations for further research will be presented.

\section{Restatement of the Problem}

While transactional distance exists in all forms of education, whether face-to-face, hybrid, or online, the degree and its impact on completion and withdrawal rate can vary (Rumble, 1986). The early studies of distance education focused primarily on structural issues and assumptions (Garrison, 2000), then shifted to the learners - their perceptions, success rates, attrition, and motivation (Chen, 2001; Chen \& Willits, 1999; Garrison, 2000; Keegan, 1986; Schlosser \& Anderson, 1994). As was stated by Moore (1993), the degree of transactional distance varies for each student and can result in making it more difficult for students to complete their courses as the distance continues to increase or decrease, as the case might be for a student. Through his or her role in course design and implementation, a faculty member can influence how students relate to the elements of transactional distance theory. Despite the indispensable role that faculty play in pedagogy, little has been done empirically to understand their perceptions of the elements of transactional distance, especially in the design, delivery, and implementation of their online courses. What roles can faculty play to help reduce that space of potential misunderstanding between their inputs and those of the learners? According to research 
conducted by Radford and the National Center for Education Statistics (2011), "student participation in a distance education course was most common among undergraduates attending public 2-year colleges; 22 percent were so enrolled" (p. 3). Thus, as the demand for these online courses continues to increase, perhaps a good understanding of factors that affect faculty perception of transactional distance might help in dealing with the elements of transactional distance, dialogue, course structure, learner autonomy, and instructor interface in order to create more conducive learning environment for successful course completion rates for the students. There is no doubt that successful online teaching depends on the individual instructor's inclinations on providing appropriate opportunities for dialogue between faculty and student, course structure, learner autonomy, and ultimately student successful completion of the course or eventual withdrawal from the course.

Four research questions guided this study: (a) What are online instructor's perceptions of the elements of transactional distance theory? (b) Is there a relationship between faculty self-reported implementation of the elements of transactional distance theory in their online courses with regard to faculty sex? (c) Is there a relationship between faculty self-reported implementation of the elements of transactional distance theory in their online courses and their number of years teaching online? and (d) Is there a relationship between faculty self-reported perceptions, on the implementations of the elements of transactional distance theory and student online course completion rates?

\section{Review of the Methods Used}

Moore's (1993) theory of transactional distance continues to generate interest in distance education, especially where technology is used to enhance the process of 
communication between teachers and students. As a pedagogical concept, the role of faculty and their actions can help to reduce transactional distance for students. Thus, based on a review of various studies dealing with transactional distance, a measurement instrument of transactional distance theory was developed by the researcher by selecting questions that have been used in other relevant studies to help understand faculty perception of transactional distance and how ultimately it relates to their online course completion rates. Because questions used on the questionnaire developed for the data gathering instrument were questions selected from prior research related to transactional distance theory, the researcher initially thought a confirmatory factor analysis would be more appropriate to use to identify the factors. However, initial analysis of the collected data revealed more than four original factors, prompting a change in data analysis to exploratory factor analysis using a principal component with varimax rotation to identify the factor components. Then, descriptive and frequency data were analyzed and presented for faculty perceptions of the elements of transactional distance theory, faculty demographic variables such as sex and number of years teaching online at the college level, and their online course completion rate for the selected course for the study.

\section{Summary of the Results}

An exploratory factor analysis revealed six factors instead of four as were identified in the original transactional distance theory. The relationship between faculty perception of transactional distance in a course and the six factors appeared strong. The relationship between faculty perception of instructor interface and transactional distance was relatively strong when compared to the other factors. 
The null hypothesis that the six factors have equal means was rejected $[F(5,357)$ $\left.=92.64, \mathrm{p}<.001, \mu^{2}=.57\right]$. Factor 1 , instructor interface, had a mean score of $76.88 \%$. Although instructor interface can be viewed as an aspect of dialogue with regard to the theory of transactional distance this factor adds a new dimension to the theory. As stated earlier, most of the studies in transactional distance have centered on student perceptions, satisfaction, and completion rates, without faculty input. Factor 2, learner-learner interaction, had a mean score of $67.42 \%$. This is in line with the theory of transactional distance. However, faculty did not perceive learner-learner interaction as high as one would expect, given that there are a myriad of technologies that can be used to facilitate that for students. Perhaps faculty did not view this as a viable means of reducing transactional distance for students. Factor 3, course structure, had the highest percentage score $(80.02 \%)$; this is in line with the theory of transactional distance and seems to support Morttera-Gterrez's (2002) assertion that an instructor's course design approach can relate to the degree of transactional distance experienced by their students. Factor 4 , instructor-learner interaction, one of the original factors of transactional distance theory, had a mean score of $75.53 \%$. It was expected that faculty would perceive this factor as essential to the degree of transactional distance that a student would experience in a course. Factory 5, learner autonomy, with a mean score of 59.77\%, did not rank as high as expected, given that technology can provide students with more opportunities to take more control of their learning. However, most faculty surveyed did not perceive this as an important way of reducing transactional distance for students. Factor 6, higher learner expectation, had a mean score of $76.13 \%$, which ranked as the third highest mean score after instructor interface. This factor is not part of the original factors of transactional 
distance theory as theorized by Moore (1993). However, this factor seems to be valued highly and seems to be perceived by the surveyed faculty as an element that can relate to transactional distance in their courses.

In support of Moore's (1993) theory of transactional distance, course structure, instructor interface, instructor-learner interaction, and higher learner expectation ranked higher than learner-learner interaction and learner autonomy. This illustrated that faculty have a high regard for dialogue and seemed to suggest that their personal interaction with students might be a positive way to reduce transactional distance for learners. The importance of the role of faculty in course design and involvement also seemed to resonate with the mean score for course structure. In Moore's original transactional distance theory, instructor-learner interaction can lower transactional distance for students, which may help increase completion rates for online students. Surprisingly, learner-learner interaction and learner autonomy did not score as high as one would expect as these are usually considered important elements in course design. Since faculty members have a direct impact on how to structure their courses to increase interaction and perhaps influence course completion rates, especially for online students, it was expected that these factors would be ranked higher. Perhaps an explanation of this low percentage for learner-learner interaction could be attributed to the fact that some of the faculty members did not design their own selected online course for this study. The faculty surveyed seemed to perceive course structure, instructor interface, instructorlearner interaction, and higher learner expectations as factors that may relate to the degree of transactional distance that a student may experience in their course and may relate to student course completion rates. 


\section{Discussion of Findings}

This section provides a detailed discussion of the findings as reported in Chapter 4 and how the findings relate to the literature review in Chapter 2 as well as to the research questions.

\section{Transactional Distance Factors Based on Research Instrument}

An exploratory factory analysis was used on the collected data to determine the underlying factors that relate to faculty perceptions of elements of transactional distance . Originally, a confirmatory factor analysis was proposed for the study; however, based on a test to find the approximate number of factors, an exploratory factor analysis was chosen since the test revealed a possibility of more than four factors.

The result of the exploratory factor analysis revealed a six factor solution. As noted in Chapter 1, Moore (1993) stated that there are three sets of variables - dialogue, structure, and learner autonomy - that determine the extent of transactional distance for students in an online course. Based on her empirical study, Chen (2001) suggested the addition of learner interface as a factor. This study suggests the further addition of instructor interface and higher learner expectation to Moore's original factors of transactional distance theory. The revelation of these two factors, instructor interface and higher learner expectation, seems to suggest that Moore's original theory of transactional distance might need to be revised to better align with web-based online courses. However, the complexity of the theory may mean that how transactional distance is perceived may be related to who is being surveyed; as a result, different audiences may have different perceptions of transactional distance and how it might relate to course completion rate for students. Thus, faculty members may perceive transactional distance 
differently than others who may be providing support for the faculty. The second research question addresses the relationship between perceptions of transactional distance and faculty sex. There were significant differences at the $\alpha=.05$ level between the mean scores of men and women on the total score of transactional distance theory on each of the six factors. However, the effect size of faculty sex also was low with maximum $\eta=$ .123. More female faculty scored higher than male faculty in all the six factors of transactional distance theory as measured with the research instrument. This seems to support Ou's (2012) call for a re-evaluation of certain faculty characteristics, such as sex, in the new paradigm of distance education. More female faculty members seemed to have ranked higher than men all the factors that relate to transactional distance. It would be interesting to know whether these differences also translate in higher completion rates for students. This was not one of the research questions for this study.

The third question was answered with a Pearson correlation between the scores on elements of transactional distance theory and the number of years faculty have been teaching online. All of the six factors, instructor interface, learner-learner interaction, course structure, instructor-learner interaction, learner autonomy and higher learner expectations, showed significant correlations between number of years of faculty has been teaching online. The correlation between the number of years teaching online and instructor interface had the highest correlation $[r(348)=.22, p<.001]$. These significant correlations tend to suggest that the number of years teaching online might make a difference in how faculty perceive the elements of transactional distance theory and perhaps might affect their implementations of these elements in their online courses and, ultimately, the degree of transactional distance experienced by their students in online 
course completion rate. Again, this seems to support the notion that experience also might make a difference in faculty perception and implementation of the elements of transactional distance theory.

The fourth and final question was answered with multiple regression analysis. The analysis indicated that faculty scores on their perception of two of the factors (instructor interface and instructor-learner interaction) of transactional distance theory as measured by the survey instrument designed for this study explained only $12 \%$ of the variance $\left[R^{2}\right.$ $=.12, F(6,355)=7.70, p<.01]$. According to Green and Salkind $(2011), 12 \%$ can be interpreted as small amount of variance in behavioral sciences. These findings tend to support Chen (2001) finding that learner interface and, based on the result of this study, that instructor interface are critical in an online course and should be included as one of the elements of transactional distance theory. Perhaps, instructor interface also should be included as an important factor. It also supports the current importance and growth of learning management systems in online courses. Perhaps institutions should endeavor to provide faculty training to ensure that faculty are familiar with all the online course flexibilities that are provided to meet the needs of both students and instructors. This training, when properly implemented, perhaps could provide faculty with more flexible means of interacting and engaging students and ultimately assist in reducing the transactional distance for their students in a course, especially for online courses.

\section{Limitations of the Study}

One of the major limitations of this study was the reliance on faculty members to select an online course to be used for the survey and to base all questions on that online course. This may have been confusing for some faculty as some may have relied on their 
memory instead of actual records to complete the survey. A possible solution might be to obtain enrollment data and completion rate from institutional records. Another solution might be a combination of the online survey and a face-to-face interview, which would allow the researcher an opportunity to collect and review this data with the faculty after they have completed the online survey.

The second limitation of the study was lack of providing incentive for faculty to complete the online survey. Despite asking institutional individuals to send a prenotification e-mail encouraging their faculty members to respond to the survey, some of the faculty members did not respond. This might be attributed to a demanding schedule as most are teaching full-time, both face-to-face and online. One solution might be to provide an incentive, which may have made a difference in survey completion rate. However, in this study, none was offered.

The third limitation was the difficulty in asking faculty members to make a judgment as to how to rate their students' perception of the elements of transactional distance theory. Since they were being asked to report on how they vicariously perceive their students' perception of elements of transactional distance, this might not translate into the exact feeling that their students have about these elements in their actual course. Once solution might be to include actual student perceptions of these elements and how it relates to their online course completion, and combine those perceptions with faculty perceptions.

\section{Implications for Research}

Transactional distance theory seems to be a complex and complicated model and may need to be refined in order to reflect and to include current changes in technology, 
especially the offering of online courses. The two additional factors identified by this study, instructor interface and higher learner expectation, seem to align with the suggestion made by Chen (2001) that the theory of transactional distance is complex, and need to be examined more closely. Given this study centered on the perceptions of faculty, it showed that faculty members equally are concerned about how they relate to their students and the interface they may be required to use.

Therefore, instructor interface is critical for faculty to be familiar with all the possible means to relate to their students and how to best take advantage of communication features available in most management system in order to help reduce the transactional distance between them and their students. This finding is important to all who work with faculty, including faculty trainers and those who provide support to faculty, especially instructional designers, lab technicians, and the institution in general. It is not enough to provide a learning management system; institutions should go above and beyond in offering faculty training and support so faculty are able to use this training appropriately to assist their students and also to help reduce transactional distance for their students, especially those online. It is important for faculty to understand how to take advantage of what is available in their learning management system in their other instructional tools that they use to engage and supporting teaching and learning.

The other factor, higher learner expectations, also supported the existing educational philosophy that students tend to perform to expectation. Therefore when faculty have higher expectation for students it might help in reducing the degree of transactional distance for the students especially for online students. 
To better understand transactional distance and how to reduce it for students to increase successful online course completion, a solution might be a study that integrates a measure of faculty input in course design and implementation and a measure of how to directly relate these measures to their student online course performance, outcome, and assessment.

\section{Recommendations for Further Research}

Transactional distance theory remains intriguing, with great potential to improve how faculty can continue to play an indispensable role in how courses are designed, orchestrated, and delivered in order to reduce transactional distance for students and increase course completion rate, especially for online courses.

Since elements of transactional distance relate to students, it important to include student input on how they experience these elements directly, rather than relying solely on faculty perceptions. Perhaps, a comparative study of those who completed and those who withdrew from an online course needs to be undertaken. This study might include separate questions for each group on how they perceive these elements of transactional distance. This type of comparative study that includes both faculty and student perceptions might better reveal the factors that directly affect the degree of transactional distance for all students, including completers and non-completers. 


\section{REFERENCES}

Angelino, L. M., Williams, F. K., \& Natvig, D. (2007). Strategies to engage online students and reduce attrition rates. The Journal of Educators Online, 4(2), 1-14.

Bacchus, C. B., Frankson, M., Chabalengula, V. M., \& Bassoppo-Moyo, T. C. (2007). Hypermedia versus traditional classroom instruction: A look at the research designs, methods, and theoretic perspectives. International Journal of Instructional Media, 24(3), 255-264.

Basow, S. (1995). Student evaluation of college professors: When gender matters. Journal of Educational Psychology, 87(4), 656-665.

Barrett, K. J., Bower, B. L., \& Donovan, N. C. (2007).Teaching styles of community college instructors. The American Journal of Distance Education, 21(1), 37-49.

Beaudoin, M. F. (2002). Learning or lurking? Tracking the "invisible" online student. Internet and Higher Education, 5(2), 147-155.

Benson, A. D., Johnson, S. D., Taylor, G. D., Treat, T., Shinkareva, O. N., Duncan, J. (2005). Achievement in online and campus-based career and technical education (CTE) courses. Community College Journal of Research and Practice, 29, 369394.

Bernard, R. M., Abarmi, P. C., Lou, Y., Borokhovski, E., Wade, A., Wozney, L., Wallet, P., A., Fiset, M., \& Huang, B. (2009). How does distance education compare with classroom instruction? A meta-analysis of the empirical literature. Review of Educational Research, 74(3), 379-439.

Braun, T. (2008). Making a choice: The perceptions and attitudes of online graduate students. Journal of Technology and Teacher Education, 16(1), 63-92.

Cain, D. L., \& Pitre, P. E. (2008). The effects of computer mediated conferencing and computer assisted instruction on student learning outcomes. Journal of Asynchronous Learning Networks, 12(3-4), 31-51.

Chen, Y. (1997). The implications of Moore's theory of transactional distance in a videoconferencing learning environment (Doctoral dissertation). Retrieved from ProQuest Digital Dissertations. (AAT 9802605)

Chen, Y. (2001). Dimensions of transactional distance in the world wide web learning environment: A factor analysis. British Journal of Educational Technology, 32(4), 459-470. 
Chen, Y. J., \& Willits, F., K. (1998). A path analysis of the concepts in Moore's theory of transactional distance in a videoconferencing learning environment. The Journal of Distance Education, 13(2), 51-65.

Cohen, J. (1988). Statistical power analysis for the behavioral sciences. Hillsdale, NJ: Erlbaum.

Garrison, R. (2000). Theoretical challenges for distance education in the 21st century: A shift from structural to transactional issues. International Review of Research in Open and Distance Learning, 1(1), 1-17.

Garrison, R. (2003). Getting the mix right again: An updated and theoretical rationale for interaction. International Review of Research in Open and Distance Learning, $4(2), 1-14$.

Goel, L., Zhang, P., \& Templeton, M. (2012). Transactional distance revisited: Bridging face and empirical validity. Computers In Human Behavior, 28(4), 1122-1129.

Green, S. B., \& Salkind, N. J. (2011). Using SPSS for Windows and Macintosh: Analyzing and understanding data. Upper Saddle River, N J: Pearson Prentice Hall.

Hagedorn, L., \& Laden, B. (2002). Exploring the climate for women as community college faculty. New Directions For Community Colleges, 2002(118), 69-78.

Hauser, R., Paul, R., \& Bradley, J. (2012). Computer self-efficacy, anxiety, and learning in online versus face to face medium. Journal Of Information Technology Education: Research, 11,141-154.

Hernandez, R. J. (2008). Development and validation of an instrument to predict online student success using faculty perceptions. (Ed.D. dissertation). Retrieved from ProQuest Digital Dissertations. (AAT 33533583)

Hopper, D. (2000). Learner characteristics, life circumstances and transactional distance in a distance education setting (Unpublished doctoral dissertation). Wayne State University, Detroit, MI.

Horzum, M. (2011). Developing transactional distance scale and examining transactional distance perception of blended learning students in terms of different variables. Educational Sciences: Theory And Practice, 11(3), 1582-1587.

Hsiu-Mei, H. (2002).Student perceptions in an online mediated environment. International Journal of Instructional Media, 29(4), 405-422. 
Kanuka, H., Collectt, D., \& Caswell, C. (2002). University instructor perceptions of the use of asynchronous text-based discussion in distance courses. American Journal of Distance Education, 16(3), 151-167

Lally, V., \& Barrett, E. (1999). Building a learning community on-line: Towards socio academic interaction. Research Papers in Education, 14(2), 147-163.

Mansour, B. E., \& Mupinga, D. M. (2007, March). Students' positive and negative experience in hybrid and online classes. College Study Journal, 41(1), 242.

Mitchell, L. G. (2008). Online education in a community college: Individual, group, and organizational perceptions of change (unpublished doctoral dissertation). Central Michigan University, Mt. Pleasant, MI.

Montera-Gutierrez, F. (2002). Instructor interactions in distance education environments. Journal of Interactive Learning Research, 13(3), 191-209.

Moore, M. G. (1990). Recent contributions to the theory of distance education. The Journal of Open and Distance Learning, 5(3), 10-15.

Moore, M. G. (1993). Theory of transactional distance. In D. Keegan (Ed.), Theoretical principles of distance education (pp. 22-38). New York: Routledge.

Moore, M. G., \& Kearsley, G. (2005). Distance education: A systems view (2nd ed.). Belmont, CA: Thomson Wadsworth.

Ni, S. (2004). Teacher verbal immediacy and sense of classroom community in online classes: Satisfaction, perceived learning, and online discussion (unpublished doctoral dissertation). University of Kansas, Lawrence, KS.

Oblender, T. E. (2002). A hybrid course model: one solution to the high online drop-out rate. Learning and leading with technology, 29(6), 42-46.

Ou, L. L. (2012). Student evaluation of instruction: In the new paradigm of distance education. Research in Higher Education, 53(4), 471-486.

Park, J. H., \& Choi, H. J. (2009). Factors influencing adult learners' decision to drop out or persist in online learning. Educational Technology and Society, 12(4), 207-217.

Powers, S., Janz, K., Ande, T. (2006). Using theories of social presence and transactional distance to understand technology enhanced instruction. In C. Crawford et al. (Eds.), Proceedings of Society for Information Technology and Teacher Education International Conference 2006 (pp. 502-505). 
Puzziferro, M., \& Shelton, K. (2008). A model for developing high-quality online courses: Integrating a systems approach with learning theory. Journal of Asynchronous Learning Networks, 12(3-4), 119-136.

Qualtrics. (Survey software). Provo, UT: Qualtrics.

Rabinovich, T. (2009). Transactional distance in a synchronous web-extended classroom learning environment (unpublished doctoral dissertation). Boston University, Boston, MA.

Radford, A. (2011). Learning at a distance: Undergraduate enrollment in distance education courses and degree programs (Stats in Brief, NCES 2012-154). Retrieved from National Center For Education Statistics website: http://nces.ed.gov/pubs2012/2012154.pdf

Ramanau, R. (2004). The impact of web-based instruction on transactional distance. In L. Cantoni, \& C. McLoughlin (Eds.), Proceedings of World Conference on Educational Multimedia, Hypermedia and Telecommunications (pp. 3707-3710). Chesapeake, VA: AACE.

Rao, N., \& Sachs, J. (1999). Confirmatory factor analysis of Chinese version of the motivated strategies for learning questionnaire. Educational and Psychological Measurement, 59(6), 1016 -1029.

Reiser, R. (2001). A history of instructional design and technology and technology: Part II: A history of instructional media. Educational Technology Research and Development, 49(2), 57-67.

Roberts, J. K. (2009). Basic concepts of confirmatory factor analysis. Paper presented at the annual meeting of the Southwest Educational Research Association. San Antonio, TX, January 12-23.

Roblyer, M., \& Wiencke, W. (2003). Design and use of a rubric to assess and encourage interactive qualities in distance courses. American Journal of Distance Education, 17(2), $77-98$.

Rovai, A. (2001). Building classroom community at a distance: A case study. Educational Technology Research and Development, 49(4), 33-48.

Rovai, A. (2003). In search of higher persistence rates in distance education online programs. Internet and Higher Education, 6(1), 1-16.

Rumble, G. (2001). Re-inventing distance education, 1971-2001. International Journal of LifeLong Education, 20(1/2), 31-43. 
Russell, T. (2002). The no significant difference phenomenon. Retrieved from No Significant Difference website: http://www.nosignificantdifference.org/

Ryan, T., Toye, M., Charron, K., \& Park, G. (2012). Learning management system migration: An analysis of stakeholder perspectives. International Review Of Research In Open \& Distance Learning, 13(1), 220-237.

Saba, F., \& Shearer, R., L. (1994). Verifying key theoretical concepts in a dynamic model of distance education. American Journal of Distance Education, 8(1), 36-59.

Schlosser, C., A., \& Anderson, M., L. (1994). Distance education: Review of the literature (Report No. ISBN-0-89240-0714). Ames, IA: Distance Education Alliance, Iowa State University of Science and Technology. Retrieved from ERIC database. (ED382159)

Sahin, S. (2006). The relationship between learner characteristics and the perception of distance learning and satisfaction with Web-based courses (unpublished doctoral dissertation). Iowa State University, Ames, IA.

Schwartzman, R. (2007). Electronifying oral communication: Refining the conceptual framework for online instruction. College Student Journal, 41(1), 37-49.

Seung, H. J. (2005). Analyzing student-student and student-instructor interaction through multiple communication tools in web-based learning. International Journal of Instructional Media 32(1), 59-67.

Shannon, D. M., \& Bradshaw, C. C. (2002). A comparison of response rate, response time, and costs of mail and electronic surveys. Journal Of Experimental Education, 70(2), 179-192.

Shea, P., Swan, K., \& Pickett, A. (2004). Teaching presence and establishment of community in online learning environments. In Sloan Consortium Summer Workshops.

Shin, N., \& Chan, J. (2004). Direct and indirect effects of online learning on distance education. British Journal of Educational Technology, 35(4), 275-288.

Song, H. (2004). A study of selected factors related to satisfaction among students enrolled in online courses at Southwest Baptist Theological Seminary (Unpublished doctoral dissertation). Southwest Baptist Theological Seminary, Fort Worth, TX.

Stein, D. S., Wanstreet, C. E., Calvin, J., Overtoom, C., \& Wheaton, J. E. (2005). Bridging the transactional distance gap in online learning environments. American Journal of Distance Education, 19(2), 105-118. 
Steinman, D. (2007). Educational experience and the online student. TechTrends, 51(5), 46-52.

Steven, J. (1990). Intermediate statistics a modern approach. Hillsdale, NJ: Lawrence Erlbaum Associates, Inc.

Summers, J.J, Waigandt, A., \& Whittaker, T. A. (2005). A comparison of student achievement and satisfaction in an online versus a traditional face-to-face statistics class. Innovative Higher Education, 29(3), 233-250.

Swan, K. (2004). Learning online: current research on issues of interface, teaching presence and learner characteristics. In J. Bourne, \& J. C. Moore (Eds.), Elements of Quality Online Education, Into the Mainstream (pp. 63-79). Needham, MA: Sloan Center for Online Education.

Sweller, J., van Merrienboer, J., \& Paas, F. G. W. C. (1998). Cognitive architecture and instructional design. Educational Psychology Review, 10(3), 251-296.

Urtel, M. G. (2008). Assessing academic performance between traditional and distance education course formats. Educational Technology \& Society, 11(1), 322-330.

Vandergrift, K. E. (2002). The anatomy of distance education course: A case study analysis. Journal of Asynchronous Learning Network, 6(1), 76-90.

Wagner, E. (1994). In support of a functional definition of interaction. American Journal of Distance Education, 8(3), 6-29.

Wheeler, S. (2007). The influence of communication technologies and approaches to study on transactional distance in blended learning. ALT-J: Research In Learning Technology, 15(2), 103-117.

Wilkes, R. B., Simon, J. C., Brooks, L. D. (2006). A comparison of faculty and undergraduate students' perceptions of online courses and degree programs. Journal of Information Systems Education, 17(2), 131-140.

Zhang, A. (2003). Transactional distance in web-based college learning environments: Toward measurement and theory construction (Unpublished doctoral dissertation). Virginia Commonwealth University, Richmond, VA. 
APPENDICES 


\section{Appendix A}

\section{Questionnaire and Consent}

\section{A Survey of Faculty Perceptions of the Structure and Characteristics of Online Courses}

\section{General Instructions}

Please, read each question carefully and answer them honestly. There is no right or wrong answer, only your answer. Responses to the survey will be reported in aggregate form, thus protecting your identity.

To answer the items on this questionnaire, please select one semester which you taught a specific online course. Then use that course as your point of reference for answering all the questions. All your responses are expected to relate to that online reference course.

\section{Instructions for Part A}

Using the course you have selected to be your online reference course, please, answer the following questions to the best of your recollections about the online course.

1. Enter number of students enrolled in your online reference course. (Please, be as exact as possible.)

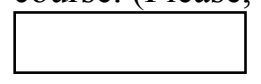

2. Enter the number of students who completed your Online reference course. (Please, be as exact as possible.)

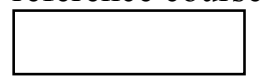

3. How many years have you been teaching Online courses at the Community College level? (Please, be as exact as possible. Enter a number between 0 and 100.)

4. How many years have you been teaching at the Community College level? (Please, be as exact as possible. Enter a number between 0 and 100.) 


\section{Instructions for Part B}

How often did you do each of the following? (Scale: $1=$ Never, $2=$ Sometimes, $3=$ Often, $4=$ Very often).

5. Make course announcements to students in this course.

6. Discuss comments that you made on one or more assignments for your students.

7. Encourage your students to ask questions about course material.

8. Provide instant feedback to students on course related content questions.

9. Provide feedback to students on questions that are not course related.

\section{Instructions for Part C}

Please rate the statements in questions 11 through 17 using the following scale: 1=Unimportant, 2=Somewhat Unimportant, 3=Important, 4=Very Important).

10. Encouraging students to take responsibility for their learning.

11. Having students find additional learning resources (library, online links, etc.).

12. Requiring students to complete course assignments on fixed deadlines.

13. Having students work in teams/groups to collaboratively complete assignments.

14. Encouraging students to spend more time focused on their studies.

15. Providing guidance on how to effectively work in groups to enable them complete group work.

16. Having students search for answer to their question rather than providing it to them or having them ask other students.

17. Providing flexible course scheduling to accommodate online discussions, assignments, etc.

\section{Instructions for Part D}

How often did your students engaged in the following online activities on a weekly basis? (Scale: $1=$ Never, $2=$ Sometimes, $3=$ Often, $4=$ Very Often.)

18. Actively participate in online group chat discussions with other students. 
19. Contribute in online threaded discussions with other students.

20. Critique fellow students work before turning it in.

\section{Instructions for Part E}

Please indicate your level of agreement with each of the following statements. (Scale: 1=Strongly Disagree, 2=Disagree, 3=Agree, 4=Strongly Agree.)

21. Students should be allowed to self-select course content.

22. Course syllabus should be followed strictly as specified.

23. All students must turn in assignments using specific format.

24. It is important for all students to have the same experience in an online course.

\section{Instructions for Part F}

Indicate how strongly you agree or disagree with each of the following statements. (Scale: 1=Strongly Disagree, 2=Disagree, 3=Agree, 4=Strongly Agree.)

25. Our learning management system provides sufficient tools for interactive learning.

26. Our learning management system enables me to manage all aspects of my online course in an efficient way.

27. Our learning management system enhances my online teaching.

28. Our learning management system provides a good teaching environment for me.

29. Technical support is readily available to me.

30. I am comfortable using our learning management system to fully engage and meet the needs of my online students.

31. My online students are comfortable using the learning management system features required for the course.

32. I spend too much time trying to use our learning management system to help my students.

\section{Instructions for Part G}

Please rate your agreement or disagreement using the following. (Scale: 1=Strongly Disagree, 2=Disagree, 3=Agree, 4=Strongly Agree.)

33. Students should have access to online management system $24 / 7$. 
34. Having students initiate and take active role in leading discussions using chat or instant messaging.

35. Having students summarize group threaded discussions before adding their own comments.

36. Having students search for answers to their questions rather than providing it for them.

37. Having students apply what they are learning to real world situations.

38. Scaffolding students' learning while remaining invisible to them.

\section{Instructions for Part $\mathrm{H}$}

39. My online course used the following media types.

(Please check all that apply).

Face-to-face

$\Gamma$ Video conferencing

Synchronous audio

$\ulcorner$ Text-based chat

E-mail

$\Gamma$ Threaded discussion

Asynchronous audio

$\ulcorner$ Course management Program (e.g., Angle)

\section{Instructions for Part I}

\section{Please answer the following questions to conclude this survey.}

40.

How were you trained in the use of technology for teaching your online class?
C Attended college provided workshops
C Tutored face-to-face by a colleague
C Self-trained
C Attended professional or commercial workshop
C Other 
41. How would you classify the content of your online course? (Please select one.)

C Mostly theoretical content

C Somewhat more theoretical than practical (applied) content

C Mostly theoretical content

C Mostly practical (applied) content

42. What is your highest educational degree?

(Please select one.)
C Doctoral
C Masters
C Bachelor
C Less than Bachelor

43. Does your reference online course satisfy any of the following?
C Remedial education Courses
C Lower division (100-200)
C Upper division (300 - 400)
C Don't know

44. Approximately, how many hours per week did you spend teaching your online class (including preparation, student contact, grading assignments, etc.)
C 5 or fewer hours
C 6-10 hours
C 11-15 hours
C 16-20 hours
C 21 hours or more

45. I designed and developed my online course. 


\section{$\mathbf{C}_{\text {Yes }}$ \\ C No}

46. How many online courses have you taught including the ones that you are teaching now?

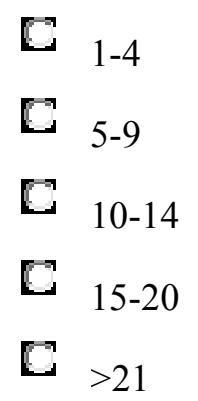

What is your sex?

47. $\quad \mathbf{C}_{\text {Female }}$

Thank you for your time in completing this survey. 
Appendix B

Factor Loading 


\begin{tabular}{|c|c|c|c|c|c|c|}
\hline \multirow[b]{2}{*}{ Item } & \multicolumn{6}{|c|}{ Loadings } \\
\hline & $\begin{array}{l}\text { Instructor } \\
\text { Interface }\end{array}$ & $\begin{array}{l}\text { Learner- } \\
\text { Leaner } \\
\text { Interaction }\end{array}$ & $\begin{array}{l}\text { Course } \\
\text { Structure } \\
\end{array}$ & $\begin{array}{l}\text { Instructor- } \\
\text { Learner } \\
\text { Interaction }\end{array}$ & $\begin{array}{l}\text { Learner } \\
\text { Autonomy }\end{array}$ & $\begin{array}{l}\text { Higher } \\
\text { Learner } \\
\text { Expectation }\end{array}$ \\
\hline $\begin{array}{l}\text { Our learning management system enables me to } \\
\text { manage all aspects of my on-line course in an } \\
\text { efficient way. }\end{array}$ & .840 & .187 & .058 & .088 & .044 & .117 \\
\hline $\begin{array}{l}\text { Our learning management system provides a good } \\
\text { teaching environment for me. }\end{array}$ & .811 & .271 & 106 & .155 & 206 & .098 \\
\hline $\begin{array}{l}\text { Our learning management system enhances my on- } \\
\text { line teaching. } \\
\text { Our learning management system nrovides }\end{array}$ & .806 & .221 & .137 & .180 & .221 & .043 \\
\hline $\begin{array}{l}\text { Our learning management system provides } \\
\text { sufficient tools for interactive learning. } \\
\text { I am comfortable using our learning management }\end{array}$ & .774 & .098 & .170 & .264 & .187 & 159 \\
\hline $\begin{array}{l}\text { system to fully engage and meet the needs of my } \\
\text { on-line students. } \\
\text { My on-line students are comfortable using the }\end{array}$ & .748 & .090 & .298 & .136 & .141 & .200 \\
\hline $\begin{array}{l}\text { learning management system features required for } \\
\text { the course. }\end{array}$ & .744 & .324 & 146 & .027 & .140 & 144 \\
\hline Technical support is readily available to me. & .583 & .220 & .301 & .113 & .322 & -.046 \\
\hline $\begin{array}{l}\text { Critique fellow student's work before that work is } \\
\text { turned in for your grading. } \\
\text { I spend too much time trying to use our learning }\end{array}$ & .224 & .781 & -.080 & .082 & -.020 & -.044 \\
\hline $\begin{array}{l}\text { 1 spend too much time trying to use our learning } \\
\text { management system to help my students. } \\
\text { Students should summarize group threaded }\end{array}$ & .140 & .777 & -.103 & -.109 & .076 & .178 \\
\hline $\begin{array}{l}\text { discussions before adding their own comments. } \\
\text { Provide feedback to students on questions that are }\end{array}$ & .175 & .706 & .282 & .154 & .264 & .004 \\
\hline $\begin{array}{l}\text { not course related. } \\
\text { I provide help to students' learning "scaffolding" }\end{array}$ & .040 & .592 & .000 & .558 & .041 & 127 \\
\hline while remaining invisible to them. & .236 & .565 & .363 & .098 & .318 & -.050 \\
\hline Students should initiate and take active role in & .060 & .564 & .491 & .137 & .186 & .065 \\
\hline
\end{tabular}




\begin{tabular}{|c|c|c|c|c|c|c|}
\hline \multirow[b]{2}{*}{ Item } & \multicolumn{6}{|c|}{ Loadings } \\
\hline & $\begin{array}{l}\text { Instructor } \\
\text { Interface }\end{array}$ & $\begin{array}{l}\text { Learner- } \\
\text { Leaner } \\
\text { Interaction }\end{array}$ & $\begin{array}{l}\text { Course } \\
\text { Structure } \\
\end{array}$ & $\begin{array}{l}\text { Instructor- } \\
\text { Learner } \\
\text { Interaction }\end{array}$ & $\begin{array}{l}\text { Learner } \\
\text { Autonomy }\end{array}$ & $\begin{array}{l}\text { Higher } \\
\text { Learner } \\
\text { Expectation }\end{array}$ \\
\hline $\begin{array}{l}\text { leading discussions using chat or instant } \\
\text { messaging. }\end{array}$ & & & & & & \\
\hline $\begin{array}{l}\text { Students should be allowed to self-select course } \\
\text { content. }\end{array}$ & .413 & .562 & .110 & -.049 & -.028 & .005 \\
\hline $\begin{array}{l}\text { It is important for students to have the same } \\
\text { experience in an on-line course. }\end{array}$ & .351 & .549 & .248 & .105 & -.158 & .297 \\
\hline $\begin{array}{l}\text { Actively participate in on-line group chat } \\
\text { discussions with other students. }\end{array}$ & .216 & .517 & .091 & .200 & .165 & -.123 \\
\hline $\begin{array}{l}\text { Contribute in on-line threaded discussions with } \\
\text { other students. }\end{array}$ & .361 & .374 & .320 & .301 & -.068 & .011 \\
\hline $\begin{array}{l}\text { Students should have access to on-line management } \\
\text { system } 24 / 7 \text {. }\end{array}$ & .214 & -.037 & .735 & .271 & .326 & .149 \\
\hline $\begin{array}{l}\text { Students should apply what they are learning to real } \\
\text { world situations. }\end{array}$ & .261 & .092 & .710 & .195 & .276 & .042 \\
\hline $\begin{array}{l}\text { All students must turn in assignments using } \\
\text { specific format. }\end{array}$ & .243 & .197 & .649 & .178 & .044 & .350 \\
\hline $\begin{array}{l}\text { Course syllabus should be followed strictly as } \\
\text { specified. }\end{array}$ & .373 & .156 & .588 & .149 & -.031 & .428 \\
\hline $\begin{array}{l}\text { Encourage your students to ask questions about } \\
\text { course material. }\end{array}$ & .223 & -.025 & .149 & .780 & .045 & .110 \\
\hline $\begin{array}{l}\text { Make course announcements to students in this } \\
\text { course. }\end{array}$ & .076 & .020 & .366 & .611 & .191 & .054 \\
\hline $\begin{array}{l}\text { Discuss comments that you made on one or more } \\
\text { assignments for your students. }\end{array}$ & .315 & .378 & .181 & .602 & -.080 & .182 \\
\hline $\begin{array}{l}\text { Provide feedback to students on course related } \\
\text { content questions. }\end{array}$ & .325 & .184 & .307 & .579 & .426 & .121 \\
\hline Having students search for answer to their question & .088 & .046 & .141 & -.108 & .636 & .353 \\
\hline
\end{tabular}




\begin{tabular}{|c|c|c|c|c|c|c|}
\hline \multirow[b]{2}{*}{ Item } & \multicolumn{6}{|c|}{ Loadings } \\
\hline & $\begin{array}{l}\text { Instructor } \\
\text { Interface }\end{array}$ & $\begin{array}{l}\text { Learner- } \\
\text { Leaner } \\
\text { Interaction }\end{array}$ & $\begin{array}{l}\text { Course } \\
\text { Structure } \\
\end{array}$ & $\begin{array}{l}\text { Instructor- } \\
\text { Learner } \\
\text { Interaction }\end{array}$ & $\begin{array}{l}\text { Learner } \\
\text { Autonomy }\end{array}$ & $\begin{array}{l}\text { Higher } \\
\text { Learner } \\
\text { Expectation }\end{array}$ \\
\hline $\begin{array}{l}\text { rather than providing it to them or having them ask } \\
\text { other students. }\end{array}$ & & & & & & \\
\hline $\begin{array}{l}\text { Encouraging students to take responsibility for their } \\
\text { learning. }\end{array}$ & .250 & .215 & .104 & .306 & .628 & .054 \\
\hline $\begin{array}{l}\text { Requiring students to complete course assignments } \\
\text { on fixed deadlines }\end{array}$ & .251 & .116 & .110 & .175 & .623 & .380 \\
\hline $\begin{array}{l}\text { Providing flexible course scheduling to } \\
\text { accommodate synchronous discussions, } \\
\text { assignments, etc. }\end{array}$ & .187 & -.003 & .185 & .019 & .596 & -.024 \\
\hline $\begin{array}{l}\text { Encouraging students to spend more time focused } \\
\text { on their studies. }\end{array}$ & .186 & .071 & .105 & .091 & .163 & .793 \\
\hline $\begin{array}{l}\text { Having students find additional learning resources } \\
\text { (library, on-line inks, etc.). }\end{array}$ & .105 & -.007 & .205 & .170 & .201 & .632 \\
\hline
\end{tabular}


VITA

\section{VICTOR IKECHUKWU NWANKWO}

\begin{tabular}{|c|c|}
\hline 1986 & $\begin{array}{l}\text { B.S., Computer Science } \\
\text { Texas A \& M University } \\
\text { College Station, Texas }\end{array}$ \\
\hline 1989 & $\begin{array}{l}\text { M.P.A., Public Administration } \\
\text { Texas A \& M University } \\
\text { College Station, Texas }\end{array}$ \\
\hline $1990-2000$ & $\begin{array}{l}\text { Software Implementation Coordinator } \\
\text { Project Synergy } \\
\text { Miami Dade Community College } \\
\text { Miami, Florida }\end{array}$ \\
\hline $2006-2008$ & $\begin{array}{l}\text { Adjunct Instructor } \\
\text { College of Education } \\
\text { Florida International University } \\
\text { Miami, Florida }\end{array}$ \\
\hline $2001-2008$ & $\begin{array}{l}\text { Senior Network Analyst } \\
\text { Applications Development } \\
\text { Miami Dade Community College } \\
\text { Miami, Florida }\end{array}$ \\
\hline 2002 - Current & $\begin{array}{l}\text { Adjunct Instructor } \\
\text { School of Education } \\
\text { Miami Dade Community College } \\
\text { Miami, Florida }\end{array}$ \\
\hline 2009 - Current & $\begin{array}{l}\text { Instructional Designer / Technology Trainer } \\
\text { College Training and Development (CT\&D) } \\
\text { Miami Dade Community College } \\
\text { Miami, Florida }\end{array}$ \\
\hline
\end{tabular}

